\title{
Yeni Okuryazarlığa Genel Bir Bakış: Karar Alıcılar, Araştırmacılar ve Öğretmenler İçin Bazı Öneriler*
}

\section{An Overview of New Literacy: Some Recommendations for Policy Makers, Researchers, and Teachers}

\begin{abstract}
Ahmet YAMAÇ**
Received: 24 December 2017

Accepted: 16 March 2018

ABSTRACT: The nature of literacy as a sociocultural phenomenon has undergone regular and continuous changes. With the increase in information and communication technologies, the meaning of literacy has been extended to online reading and content creating from traditional printed material based reading and writing. These changes have brought about a rapid increase of information and communication technology usage rates. To be literate today requires new skills, strategies, practices, and dispositions as well as reading and writing skills based on traditional printed materials. In the light of these developments, the lowercase and Uppercase New Literacies Theory has emerged in order to explain and examine today's literacy, which involves many perspectives. The purpose of the current study is to review the new literacy theoretical framework, give information about recent research trends in new literacy, and make some suggestions to policy-makers, researchers and teachers. In accordance with this purpose, i) the dual-level new literacy theory is examined, ii) online reading and writing research in recent years is looked at, iii) information about technology integration in literacy education is given, iv) the concept of the digital divide is discussed and finally v) various research and practice recommendations are introduced.
\end{abstract}

Keywords: dual-level new literacy theory, online reading and writing, technology integration, digital divide.

ÖZ: Sosyokültürel bir olgu olarak okuryazarlığın doğası düzenli ve sürekli olarak değişmektedir. Artan bilgi ve iletişim teknolojileri ile birlikte okuryazarlık basılı materyallere dayalı okuma ve içerik oluşturmadan çevrim içi okuma ve anlam oluşturmaya doğru kaymaktadır. Bu dönüşümlerle birlikte bilgi ve iletişim teknoloji kullanım oranları son yıllarda hızlı bir şekilde artmıştır. Günümüzde tam manasıyla okuryazar olabilmek için geleneksel basılı materyallere dayalı okuma yazma becerilerinin yanı sıra, yeni beceri, strateji, uygulama ve eğilimler gerekmektedir. Tüm bu gelişmeler ışığında günümüz okuryazarlığını açıklamak ve incelemek amacıyla son yıllardaki birçok bakış açısını içine alan küçük harflerle ve Büyük Harflerle yeni okuryazarlık kuramı doğmuştur. Bu çalışmanın amacı yeni okuryazarlık kuramsal bakış açısını gözden geçirmek, yeni okuryazarlık üzerine son araştırma eğilimleri hakkında bilgi vermek ve karar alıcılara, araştırmacılara ve öğretmenlere bazı öneriler sunmaktır. Bu amaç doğrultusunda i) iki düzeyli yeni okuryazarlık kuramı incelenmiş, ii) son yıllardaki çevrim içi okuma ve yazma araştırmaları gözden geçirilmiş, iii) okuma yazma eğitiminde teknoloji entegrasyonu hakkında bilgi verilmiş, iv) dijital bölünme kavramı ele alınmış ve son olarak v) çeşitli araştırma ve uygulama önerileri getirilmiştir.

Anahtar kelimeler: iki düzeyli yeni okuryazarlık kuramı, çevrim içi okuma ve yazma, teknoloji entegrasyonu, dijital bölünme.

\footnotetext{
* A part of this study was presented as oral presentation at International Conference on Science and Education which was held in Afyonkarahisar on the dates of 23-24-25 March 2018.

${ }^{* *}$ Corresponding Author: Asst. Prof. Dr., Erciyes University, Kayseri, Turkey, ahmetyamac@erciyes.edu.tr
}

Citation Information

Yamaç, A. (2018). Yeni okuryazarlığa genel bir bakıș: Karar alıcılar, araştırmacılar ve öğretmenler için bazı öneriler. Kuramsal Eğitimbilim Dergisi [Journal of Theoretical Educational Science], 11(3), 383-410. 


\section{Giriş}

Sosyokültürel bir olgu olarak okuryazarlık sürekli değişen ve dönüşen bir yapıya sahiptir. 30-40 yıl önce insanlar yazılı bir metni okuyup o metinle ilgili sorulara cevap verdiklerinde, 150 yıl önce de isim ve soy isimlerini tam olarak yazdıklarında okuryazar say1lırlardı. Yoğun bir şekilde teknoloji etkisi altında olan bugünün kültürü ise insanların başarılı olmalarında yeni okuryazarlık becerilerini zorunlu kılmaktadır (Baker, Pearson \& Rozendal, 2010; Henry, 2007). Bir başka ifadeyle, 21. yüzyılda tam olarak okuryazar olabilmek için hayatın hemen hemen her boyutunu etkileyen teknolojileri kullanmada gerekli olan beceri, strateji ve eğilimleri içeren yeni okuryazarlığa sahip olmak gerekmektedir (Lapp, Moss \& Rowsell, 2012).

Okuryazarlığın doğası düzenli ve sürekli olarak değişmektedir (Leu, Kinzer, Coiro, Castek, \& Henry, 2013; Leu, McVerry, O’Byrne, Kiili, \& Zawilinski, 2011; Leu, Zawilinski, Forzani, \& Timbrell, 2015; Leu, Everett-Cacopardo, Zawilinski, Mcverry, \& O 'byrne, 2012). Üretilen teknolojiler ve sosyal güçler okuryazarlığın doğasındaki bu değişimi etkileyen başlıca faktörlerdendir (Leu ve diğerleri, 2013). Bu faktörlerin dışında ekonomik değişimler, toplumsal baskılar, demokratikleşme ve kültürel değişimler okuryazarlığın değişiminde önemli bir role sahiptir (Leu, 2000; Leu, Kinzer, Coiro, \& Cammack, 2004). Leu ve diğerleri (2013) günümüzde okuryazarlığı değişime zorlayan üç temel gücü şöyle siralamaktadır:

- Bilgi ve iletişim teknolojilerinin etkili kullanımına dayalı ekonomiler içindeki küresel ekonomik rekabet.

- İnternetin mesleki ve kişisel yaşamdaki hızlı yükselişi.

- Okuryazarlık ve interneti öğretime entegre eden siyasi girişimler.

$\mathrm{Bu}$ doğrultuda, bireylerin bilgisayar kullanma oranları da son y1llarda hızlı bir şekilde artmaktadır. Bilgi ve iletişim teknolojileri ile birlikte okuryazarlık geleneksel anlamda basılı materyallere dayalı okuma ve kâğıt-kalem kullanarak içerik oluşturmadan, çevrim içi okuma ve çevrim içi anlam oluşturmaya doğru kaymaktadır. 2010 yılında Amerika'da 8-18 yaş arası bireylerde medya kullanım oranlarının incelendiği bir çalışmada, bu yaş aralığındaki bireylerin ekrandan okuma oranı basılı materyallerde okuma oranını geçmiştir (Rideout, Foehr, \& Roberts, 2010). Benzer durum internet kullanımında da görülmektedir. Türkiye İstatistik Kurumu'nun (TUİK) (2016) hane halkı araştırmasına göre 16-74 yaş grubundaki bireylerde bilgisayar ve internet kullanım oranları sırasıyla $\% 54.8$ ve $\% 55.9$ 'dur. Türkiye genelinde evde internet bağlantısına sahiplik oranı \%73'dür. İnternet kullanım amaçlarına bakıldığında \%82'si sosyal medya kullanmak, \%75'i paylaşım sitelerinde video izlemek ve \%70'i haber-gazete okumak için interneti kullanmaktadır. Bu sonuçlar Amerika ve Türkiye'de çevrim içi okuma ve yazma davranışlarının son yıllarda hızlı bir şekilde arttığını göstermektedir.

Dünün geleneksel basılı kitapları için yeterli okuryazarlık becerileri, bugünün bilgi ve internet çağında çevremizi kuşatan Google docs, Skype, iMovie, Contribute, Basecamp, Dropbox, Facebook, Google, Foursquare, Chrome, eğitsel video oyunlar, ya da binlerce diğer uygulama ve e-kitaplar için yeterli olmayabilir (Leu ve diğerleri, 2013). Günümüzde okuryazar olmak bloglar, wikiler, internetten mesajlaşma araçları, arama motorları, Facebook, foursquare, Google Docs, Skype, Chrome, iMovie ve benzeri birçok yeni teknolojiyi kullanabilme anlamına gelmektedir (Leu ve diğerleri, 
2011). Bu uygulamalardan tam olarak faydalanabilmek ve bunları etkili bir şekilde kullanabilmek için geleneksel okuma ve yazma becerilerinin tamamlayıcısı yeni okuma ve yazma becerilerine ihtiyaç duyulmaktadır (Leu ve diğerleri, 2015).

Bilgi ve iletişim çağında okuryazarlığın anlamı değişirken tek bir bakış açısından okuryazarlığı ele almak ve tanımlamak oldukça güçleşmektedir. Yaygın bir şekilde günümüzde "yeni okuryazarlık" (new literacy) kavramı kullanılmasına rağmen, dijital okuryazarlık (digital literacy), çoklu okuryazarlık (multiliteracy) ve elektronik okuryazarlık (electronic literacy) gibi kavramların da alanyazında kullanıldığ görülmektedir. $\mathrm{Bu}$ çalışmada yeni okuryazarlık kavramı tercih edilmiştir. Leu ve diğerlerinin (2004) tanımı bu çalışmanın bakış açısını yansıtmaktadır:

İnternet ve diğer bilgi ve iletişim teknolojileri ile ilgili yeni okuryazarlık, hızla değişen bilgi ve iletişim teknolojilerine ve dünyamızda ortaya çıkan ve kişisel ve mesleki yaşamımızın tüm alanlarını etkileyen durumlara adapte olmayı ve başarılı bir şekilde kullanmayı gerektiren becerileri, stratejileri ve eğilimleri içermektedir. Bu yeni okuryazarlık kavramı önemli soruları tanımlamak, bilgiye ulaşmak, bu bilginin kullanışlılığını değerlendirmek, soruları cevaplamada bilgiyi sentez etmek ve diğerleri ile iletişime geçmek için internet ve diğer bilgi ve iletişim teknolojilerini kullanmamızı sağlamaktadır (s. 1572).

Önemli problemleri belirleyebilen, en hızlı şekilde işe yarayan bilgiye ulaşabilen, bilgiyi eleştirel olarak değerlendirebilen, en iyi çözümü bulabilmek için birçok bilgi kaynağını sentezleyebilen ve etkili bir şekilde iletişim kurabilen birey, grup ya da toplumlar günümüzde daha başarılı olacaklardır (Leu ve diğerleri, 2011). Bu anlamda günümüzde okuryazarlığın doğasının ve bireylerin sosyal ve ekonomik hayata katılmak için ihtiyaç duyduğu beceri, strateji ve eğilimlerin değiştiği görülmektedir. Öğrencilerin yeterli düzeyde okuryazar olabilmeleri internet ve bilgi iletişim teknolojilerini kullanarak dünya ile yazılı ve sözlü iletişim kurabilmelerine bağlı olduğu için öğretim programlarının ve sınıf çevrelerinin yeniden ele alınması gerektiği gerçeği ortaya çıkmaktadır. Bu çalışmada yeni okuryazarlığın dayandığı kuramsallar temeller ele alınmış, bilgi ve iletişim teknolojilerinin okuma yazma eğitiminde öğretim programlarına ve sınıf çevrelerine nasıl entegre edilebileceği irdelenmiş, okuma ve yazma eğitiminde teknolojinin kullanımı ile ilgili son yıllarda yapılan araştırmalar gözden geçirilmiş, dezavantajlı bölgelerdeki öğrencilerin çevrim içi okuma ve yazma davranışları incelenmiş ve karar alıcılar, öğretmenler ve araştırmacılar için bazı öneriler getirilmiştir.

\section{İki Düzeyli Yeni Okuryazarlık Kuramı}

Sürekli değişism halinde olan bir kavramı tanımlamak oldukça zordur. Çünkü günümüz dünyasının sosyal uygulamaları ve bilgi iletişim teknolojileri sürekli değişim halindedir. Yeni bir söylem (discourse) olarak okuryazarlık (Gee \& Handford, 2013), çok biçimlilik (multimodality) (Kress, 2003), çoklu okuryazarlık (multiliteracy) (New London Group, 1996), bilgi ve İletişim teknolojileri okuryazarlığı (International ICT Literacy Panel, 2002) ve dijital okuryazarlık (Martin, 2006) gibi farklı kuram ve bakış açılarından günümüzde okuryazarlık tanımlanmaya çalışılmaktadır. Araştırmacılar bu kuram ve bakış açılarını iki düzeyli yeni okuryazarlık olmak üzere tek bir şemsiye altında toplamaya çalışmaktadır (Leu ve diğerleri, 2015; Leu ve diğerleri, 2013). Bu yaklaşım birçok bakış açısını zenginlik olarak gören açık uçlu bir girişimdir. İnternet ve okuryazarlık üzerinde çalışan herkesi kuramın geliştirilmesine destek vermeye çağırmaktadır (Leu ve diğerleri, 2012). 
İki düzeyli yeni okuryazarlık kuramı okuryazarlığı küçük harflerle ve Büyük Harflerle olmak üzere iki düzeyde ele almaktadır. Büyük Harflerle Yeni Okuryazarlık daha geniş ve kalıcıdır; iç içe geçmiş birçok bakış açısından oluşmaktadır. Küçük harflerle yeni okuryazarlık ise daha hızlı değişmektedir ve daha özel araç ya da yöntemlerden oluşmaktadır (Forzani \& Maykel, 2013; Leu ve diğerleri, 2011). Küçük harflerle yeni okuryazarlık kuramı okuryazarlığın hızla değişen doğasına daha kolay ayak uydurabilir. Bu düzey birçok bakış açısını, teknolojiyi ve uygulamayı kabul etmektedir (Leu ve diğerleri, 2015). Küçük harflerle yeni okuryazarlık, metin iletisi ile oluşan sosyal iletişim hareketleri ve çevrim içi okuduğunu anlama gibi yeni okuryazarlık ya da yeni bir teknolojinin belirli bir alanını keşfetmektedir (Leu ve diğerleri, 2013). Büyük Harflerle Yeni Okuryazarlık, küçük harflerle ortaya çıkan ortak bulguları içeren daha geniş ve daha kapsayıcı bir kavramdır. Küçük harflerle yeni okuryazarlık bakış açısını kullanan araştırmalarda ortaya çıkan ortak ve tutarlı bulgulardan faydalanmaktadır (Leu ve diğerleri, 2013; Leu ve diğerleri, 2015). Büyük Harflerle Yeni Okuryazarlık Kuramının temel ilkeleri şunlardır (Leu ve diğerleri, 2013, s.1158):

- İnternet, küresel toplum içerisinde öğrenen ve okuryazar olabilmek için günümüz neslin teknolojisidir.

- İnternet ve ilgili teknolojiler bunlardan tamamıyla faydalanmak için ek yeni okuryazarlık gerektirmektedir.

- Yeni okuryazarlık sürekli değişim halinde olan bir kavramdır.

- Yeni okuryazarlık çoklu, çok biçimli ve çok yüzlüdür.

- Eleştirel okuryazarlık yeni okuryazarlık için temeldir.

- Yeni okuryazarlıkla birlikte stratejik bilginin yeni türleri gereklidir.

- Yeni sosyal uygulamalar yeni okuryazarlığın temel bir ögesidir.

- Öğretmenler, rollerinin değişmesi ile beraber okuma yazma eğitiminde daha da önemli bir işleve sahiptirler.

Yeni okuryazarlık kuramı teknoloji ve okuryazarlık üzerine çalışan herkesi kuramın gelişimine destek olmaya davet etmektedir. Bu yaklaşım her araştırmacının yeni okuryazarlığın küçük harflerle olan bakış açısını keşfetmesine izin vermektedir. Böylece araştırmacıların okuryazarlığın farklı boyutlarına odaklanmalarını sağlamaktadır. Her araştırmacı yeni okuryazarlığın evrilen tanımına katkı yapmakta özgürdür. Yeni okuryazarlığın tanımı çoklu bakış açıları, disiplinler ve araştırma geleneklerinden beslenmektedir (Leu, Slomp, Zawilinski, \& Corrigan, 2016).

\section{Dijital Teknolojilerin Okuma Yazma Öğretim Programları ve Sınıflarına Entegrasyonu}

Bir şeyi entegre etmek demek, onu bir bütünün parçası haline getirmektir. Dijital teknolojiler okuma yazma eğitimine entegre edildiğinde, öğrenme ve öğretim sürecinin bir parçası olmuş demektir. Buradaki amaç teknoloji kullanımı değildir; öğrencilerin okuryazar olmalarına yardım etmektir. Ancak teknoloji öğrencilerin hem yazılı hem de dijital çevrede okuma yazma becerilerini geliştirmek için kullanılabilir. Teknolojiyi okuma yazma öğretimine entegre ettiğimiz zaman öğretim sürecindeki sınıf çevresi, öğretmenin rolü ve öğrencilerin rolü gibi birçok öge değişecektir (Hutchison \& Colwell, 
2015). Uluslararası Okuma Derneği'ne (2009) göre "bugünün dünyasında tamamen okuryazar olmak için öğrenciler 21. yüzyıl teknolojilerinin yeni okuryazarlığında yeterli düzeyde olmalıdırlar. Bu bağlamda, okuma yazma eğitimcileri öğrencileri hakkettikleri okuryazarlık geleceğine hazırlamak için yeni teknolojileri öğretim programına entegre etme sorumluluğu duymalıdırlar" (s.1). Ancak okullar okuma yazma eğitiminde geleneksel metinleri, inançları ve biçimleri kullanmaya devam etmektedir (Lapp diğerleri, 2012). Gelişen internet ve bilgi teknolojileri ile birlikte öğretmenlerin okuma ve yazma eğitimine entegre ederek kullanabilmeleri için dijital kitap oluşturma, dijital okuma ve yazma, çok biçimli içerik oluşturma, iş birlikli yazma ve grafik düzenleyiciler oluşturma gibi birçok araç ve uygulama ortaya çıkmıştır (Bakınız. Tablo 1).

Tablo 1

Okuryazarlık Ĕ̈itiminde Kullanılabilecek Bazı Araçve Uygulamalar

\begin{tabular}{|c|c|c|c|}
\hline Ad 1 & Uygulama adı & Tanımı & Özellikleri \\
\hline $\begin{array}{ll}\text { Dijital } & \text { kitap } \\
\text { oluşturma } & \\
\text { araçları } & \end{array}$ & $\begin{array}{l}\text { Bookcreator } \\
\text { Doodle Buddy } \\
\text { Whattpad } \\
\text { Mystoryapp }\end{array}$ & $\begin{array}{lr}\begin{array}{l}\text { Öğrencilerin } \\
\text { yazı̈larla }\end{array} & \begin{array}{r}\text { göseller ve } \\
\text { hikâye }\end{array} \\
\text { oluşturmalarını } & \text { ve } \\
\text { paylaşmalarını sağlayan } \\
\text { uygulama veya } \\
\text { siteleridir. }\end{array}$ & $\begin{array}{l}\text { Çizim, ses, resim veya video } \\
\text { ekleme } \\
\text { Metin oluşturma } \\
\text { Yayınlama ve paylaşma } \\
\text { İs birlikli yazma }\end{array}$ \\
\hline $\begin{array}{l}\text { Dijital metin } \\
\text { okuma araçları } \\
\text { ve uygulamaları }\end{array}$ & $\begin{array}{l}\text { Diigo } \\
\text { Subtext } \\
\text { Goodreader } \\
\text { Evernote } \\
\text { Kindle } \\
\text { İbooks } \\
\text { Calibre } \\
\text { Adope Acrobat Pro }\end{array}$ & $\begin{array}{l}\text { Öğrencilerin çevrim içi } \\
\text { araştırma, okuma ve bilgi } \\
\text { paylaşmalarını sağlayan } \\
\text { uygulama veya web } \\
\text { siteleridir. }\end{array}$ & $\begin{array}{l}\text { Kişisel kütüphane oluşturma } \\
\text { Geri bildirim ve tartışma } \\
\text { Okuma grupları oluşturma } \\
\text { Not alma } \\
\text { Vurgulama } \\
\text { Altını çizme } \\
\text { Şekil çizme } \\
\text { Sözlük } \\
\text { Arama } \\
\text { Yazı boyutunu değiştirme } \\
\text { Paylaşma } \\
\text { Bağlantıları organize etme }\end{array}$ \\
\hline Bloglar & $\begin{array}{l}\text { Blogger } \\
\text { Kidblog } \\
\text { Wordpress } \\
\text { Weebly } \\
\text { Edublog }\end{array}$ & $\begin{array}{ll}\text { Öğrencilerin } & \text { yazı, resim, } \\
\text { ses ya da video gibi medya } \\
\text { türlerinde paylaşımlarda } \\
\text { bulundukları ve yorum ve } \\
\text { tartışma } & \text { yapabildikleri } \\
\text { uygulama } & \text { veya web } \\
\text { siteleridir. } & \end{array}$ & $\begin{array}{l}\text { Resim, yazı, ses ve video } \\
\text { paylaşma } \\
\text { Tartışma } \\
\text { İş birlikli yazma } \\
\text { Etkileşim } \\
\text { Geri bildirim ve değerlendirme }\end{array}$ \\
\hline Mikrobloglar & Twitter & $\begin{array}{l}\text { Öğrencilerin sınırlı karakter } \\
\text { ( } 240 \text { ve daha az) kullanarak } \\
\text { yazı, resim ya da video } \\
\text { paylaşabildikleri sosyal ağ } \\
\text { sitesidir. }\end{array}$ & $\begin{array}{l}\text { Özetleme } \\
\text { Etkileşim } \\
\text { Paylaşma } \\
\text { Geri bildirim } \\
\text { İş birlikli yazma } \\
\text { Yansıtma }\end{array}$ \\
\hline
\end{tabular}


Tablo 1 (devami)

Okuryazarlık Eğitiminde Kullanılabilecek Bazı Araçve Uygulamalar

\begin{tabular}{|c|c|c|c|}
\hline Ad 1 & Uygulama adı & Tanımı & Özellikleri \\
\hline $\begin{array}{l}\text { Görsel } \\
\text { oluşturma } \\
\text { araçları }\end{array}$ & $\begin{array}{l}\text { Google Çizimler } \\
\text { Bubble.us } \\
\text { Toondoo } \\
\text { iBrainstorm } \\
\text { SpiderScribe } \\
\text { Popplet } \\
\text { Thinglink }\end{array}$ & $\begin{array}{l}\text { Öğrencilerin okudukları ya } \\
\text { da yazdıkları bir konu ya da } \\
\text { metin hakkında çeşitli } \\
\text { görseller oluşturmalarını ve } \\
\text { düzenlemelerini sağlayan } \\
\text { uygulama veya web } \\
\text { siteleridir. }\end{array}$ & $\begin{array}{l}\text { Kavram haritası oluşturma } \\
\text { Hikâye haritası oluşturma } \\
\text { Karikatür oluşturma } \\
\text { Beyin firtınası } \\
\text { Fotoğraf ve resimlere not } \\
\text { alma } \\
\text { Görsel çizme }\end{array}$ \\
\hline $\begin{array}{l}\text { İş birlikli yazma } \\
\text { araçları }\end{array}$ & Google Doküman & 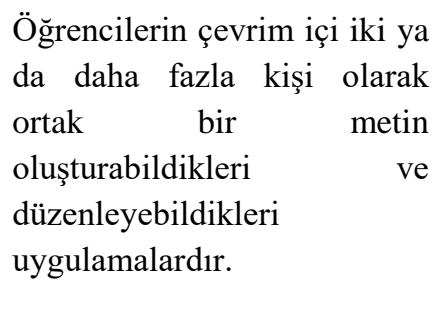 & $\begin{array}{l}\text { Geri bildirim } \\
\text { Paylaşma } \\
\text { İş birlikli yazma } \\
\text { Yansitma } \\
\text { Yorum yapma } \\
\text { Düzeltme }\end{array}$ \\
\hline Wikiler & $\begin{array}{l}\text { Wikispace } \\
\text { Wikidot }\end{array}$ & $\begin{array}{l}\text { Çevrim içi birden çok kişinin } \\
\text { iş birlikli olarak içerik } \\
\text { oluşturmalarını, } \\
\text { düzenlemelerini } \\
\begin{array}{l}\text { yayınlamalarını } \\
\text { internet sitesidir. }\end{array}\end{array}$ & $\begin{array}{l}\text { İş birlikli yazma } \\
\text { Değerlendirme } \\
\text { Paylaşma } \\
\text { Yayınlama } \\
\text { Düzenleme }\end{array}$ \\
\hline Sunum araçları & $\begin{array}{l}\text { Prezi } \\
\text { Google Slaytlar }\end{array}$ & $\begin{array}{l}\text { Çevrim içi olarak sunum } \\
\text { oluşturmaya, sunum yapmaya } \\
\text { ve kaydetmeye yarayan } \\
\text { internet siteleridir. }\end{array}$ & $\begin{array}{l}\text { Düzenleme } \\
\text { Paylaşma } \\
\text { İş birliği }\end{array}$ \\
\hline $\begin{array}{l}\text { Sosyal öğrenme } \\
\text { platformları }\end{array}$ & $\begin{array}{l}\text { Edmudo } \\
\text { Beyazpano } \\
\text { Google Sinıf }\end{array}$ & \begin{tabular}{lrr} 
Öğretmen, öğrenci ve & ve \\
velilerin etkileşimde & \multicolumn{2}{c}{ ödev verme, } \\
bulundukları ö & paylaşma \\
dosya ve & gibi \\
değerlendirme & etkinliklerin çevrim içi olarak \\
yapılabildiği sosyal öğrenme \\
platformlarıdır.
\end{tabular} & $\begin{array}{l}\text { Ödevlendirme } \\
\text { Dosya paylaşımı } \\
\text { İş birliği } \\
\text { Paylaşma } \\
\text { Yayınlama } \\
\text { Geri bildirim } \\
\text { değerlendirme } \\
\text { Duyuru } \\
\text { Dosya saklama }\end{array}$ \\
\hline $\begin{array}{l}\text { Çok biçimli } \\
\text { metin oluşturma } \\
\text { araçları }\end{array}$ & $\begin{array}{l}\text { Photostory } 3 \\
\text { Movie Maker }\end{array}$ & \begin{tabular}{lrr}
\multicolumn{3}{l}{ Öğrencilerin yazı, ses, görsel } \\
ve video & gibi & medya \\
araçlarından & oluşan & çok \\
biçimleri & metinler \\
oluşturmalarını & & sağlayan \\
programlardır. & &
\end{tabular} & $\begin{array}{l}\text { Düzenleme } \\
\text { Yazı, ses, görsel ve video } \\
\text { ekleme } \\
\text { Bütünleştirme } \\
\text { Sunma } \\
\text { İş birliği } \\
\text { Değerlendirme }\end{array}$ \\
\hline
\end{tabular}


Alanda yapılan çeşitli araştırmalar öğretmenlerin okuma yazma eğitimine dijital teknolojileri entegre etmede güçlük çektiğini göstermektedir (Hutchison \& Reinking, 2011; O’Neal, Gibson, \& Cotten, 2017). Son zamanlarda birçok araştırmacı, okuma ve yazma eğitimine tablet bilgisayarlar, çeşitli google uygulamaları, dijital metinlerde okuma ve çok biçimli metin öğretimi gibi birçok uygulamayı adapte ederek başarılı bir yeni okuryazarlık sınıfı oluşturmaya yönelik araştırmalar yapmaktadır (Hutchison, Beschorner \& Schmidt-Crawford, 2012; Hutchison \& Woodward, 2014; Larson, 2010). Bu bağlamda Hutchison ve Woodward (2014) okuma yazma ve dil öğretimi dersleri için teknoloji entagrasyonu planlama döngüsü ileri sürmüşlerdir. $\mathrm{Bu}$ döngü yedi temel ögeden oluşmaktadır: öğretim hedefi, öğretimsel yaklaşım, dijital ya da dijital olmayan araç seçimi, seçilen aracın öğretim hedefine katkısını belirleme, aracı kullanırken olası sınırlılıkları belirleme, öğretimsel hedefin revizyonu ve sonuçlar ve değişimler hakkında yansıtma yapma (Bakınız. Şekil 1).

Şekil 1. OkumaYazma ve Dil Öğretimi İçin Teknoloji Entegrasyonu Planlama Döngüsü

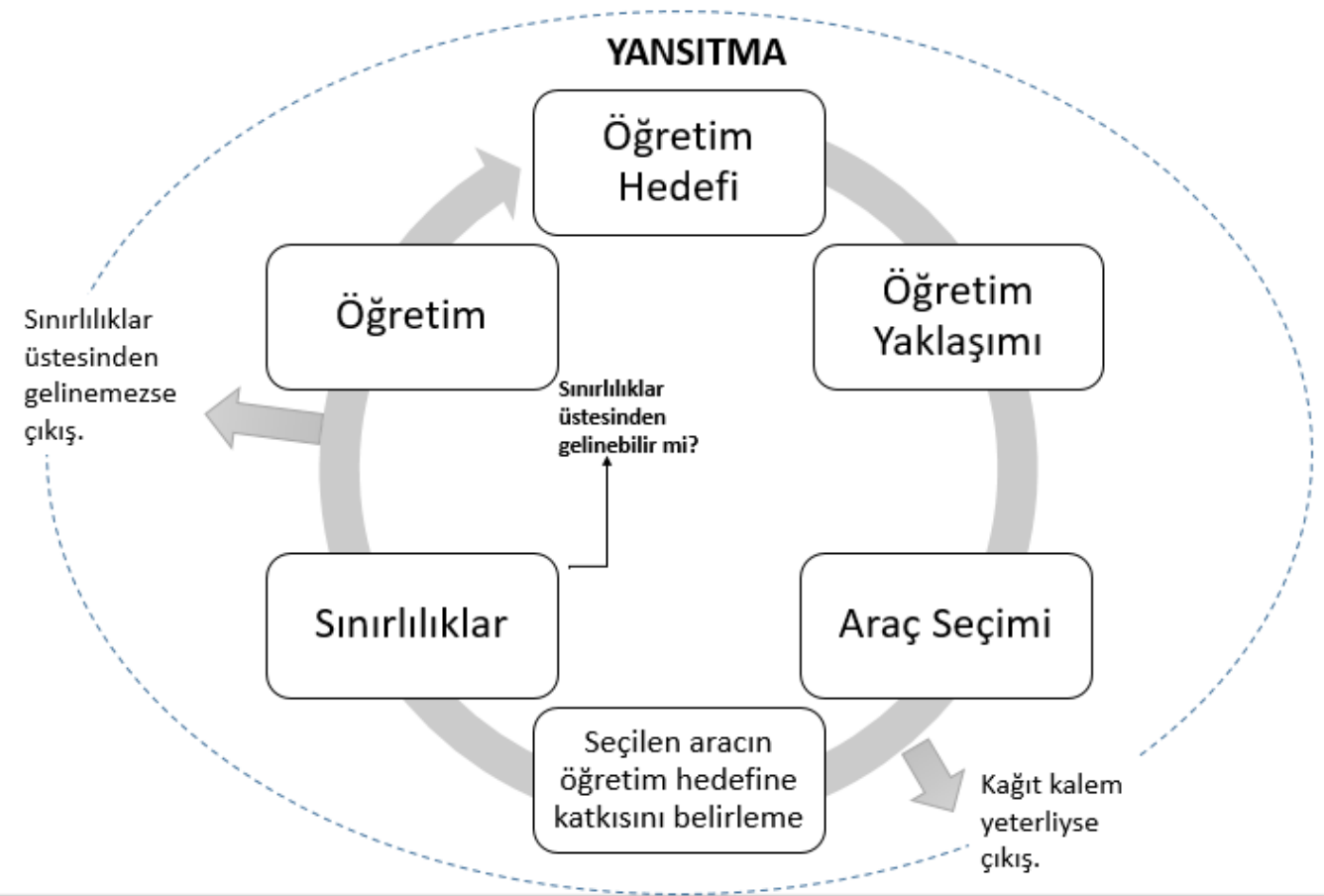

Uyarlandı̆̆ı yayın (Hutchison \& Woodward, 2014)

Teknoloji sayesinde dünya ile yeterli derecede iletişim kurabilmek için hem geleneksel hem de yeni okuma ve yazma becerilerine ihtiyaç duyulmaktadır (Baker ve diğerleri, 2010). İpadlerlerin okuma yazma eğitimine entegrasyonu ile öğrencilerin hem geleneksel okuryazarlık becerileri hem de yeni okuryazarlık becerileri geliştirilebilmektedir. Hutchison ve diğerleri (2012) yaptıkları çalışmada, ilkokul dördüncü sınıf düzeyindeki öğrencilerin hem geleneksel hem de dijital okuryazarlık becerilerinin gelişiminde İpadlerin entegrasyonunu keşfetmiş̧lerdir. 3 haftalık eğitim boyunca çeşitli bağımsız okuma, sıralama, görselleştirme, tekrar anlatma, sebep-sonuç ilişkisi kurma ve ana fikir ve detayları belirleme gibi okuma becerilerini geliştirmek için Ibooks, Popplet, Doodle Buddy ve Strip Designer gibi uygulamaları kullanmışlardır. Elde edilen bulgulara göre yeni okuryazarlık becerilerinin bazılarını tanıtarak öğretmen, 
basılı metinlere dayalı okuma-yazma hedeflerine ulaşabilmiştir. Ayrıca İPadler öğrencilere çalışmalarını kolayca düzeltme, anlamı oluşturmada renk ve şekil kullanma, metni görsel olarak sunma, kolay bir şekilde iş birliği yapma ve doğrusal olmayan okuma yazma etkinlerine katılma gibi konularda destek olmuştur. Larson (2010) ilkokul ikinci sınıf öğrencileri ile yaptığı bir çalışmada, dijital okuma araçlarının yeni okuryazarlık uygulamalarını nasıl geliştirdiğini ve okur ve metin arasındaki bağlantıları nasıl genişlettiğini araştırmıştır. Elde edilen bulgulara göre dijital not tutma araçları ikinci sınıf öğrencilerinin metne katılmalarına ve metni daha fazla kontrol etmelerine sebep olmuştur. Öğrenciler dijital okuma araçlarının potansiyeline ulaşmak için yeni okuryazarlık becerileri ve stratejilerini kullanmışlardır. Anlama sürecini desteklemek için yazı boyutunu ayarlama, kelimelerin anlamına bakmak ve yazılışını kontrol etmek için sözlük kullanma ve dijital okuma aracının metni sese dönüştürme özelliğini kullanma gibi çeşitli etkinlikler yapmışlardır.

Yapılan bazı çalışmalar okuma yazma eğitimine tablet bilgisayarlar ve diğer teknolojilerin etkili bir şekilde adapte edilebileceğini göstermekte iken (Hutchison ve diğerleri, 2012; Hutchison \& Woodward, 2014; Larson, 2010), öğretmenlerin okuma ve yazma eğitiminde teknolojiyi nasıl kullandıklarına, teknolojinin kullanımına ilişkin inançlarına ve teknoloji kullanımında ne tür engellerle karşılaştıklarına yönelik çalışmalar da mevcuttur (Anwaruddin, 2015; Beach, 2012; Hutchison, 2012; Hutchison \& Reinking, 2011; McDermott \& Gormley, 2016; O’Neal ve diğerleri, 2017; Pang, Reinking, Hutchison, \& Ramey, 2015). Hutchison ve Reinking (2011) 1441 okuma ve yazma eğitimcisi ile yaptıkları çalışmada, öğretmenlerin bilgi ve iletişim teknolojilerini okuma ve yazma eğitimine entegre etme ile ilgili algılarını araştırmışlardır. Öğretmenlerin hemen hemen tamamı teknolojinin okuma ve yazma eğitimine entegre edilmesi gerektiğini düşünmekle birlikte üçte ikisi teknolojinin geleneksel eğitimi tamamlayıcı bir rolünün olması gerektiğini belirtmiştir. Öğretmenlerin büyük çoğunluğu teknolojiyi okuma ve yazma eğitimine entegre etmede kendine güvenmektedir. Sınıfta teknolojinin kullanımında en çok ifade edilen engeller zaman eksikliği, teknik destek ve mesleki gelişim eksikliği olarak ortaya çıkmıştır. O’Neal ve diğerleri (2017) ilkokul öğretmenleri ile yaptıkları nitel bir çalışmada, öğrenme ve öğretimde teknolojinin rolüne ilişkin onların inançlarını araştırmışlardır. Elde edilen bulgular öğretmenlerin öğrenme ve öğretimde teknolojinin kullanımına değer verdikleri ancak daha fazla rehberliğe ihtiyaç duyduklarını göstermişstir.

\section{Teknoloji ve Çevrim İçi Okuma Üzerine Yapılan Araştırmalar}

“İnternet bir teknoloji konusu değildir, okuma ve okuryazarlık konusudur" (Leu, 2006, s.6). Geleneksel anlamda okuma, basılı materyallere dayalı okumadır. Geleneksel anlamda okuma için okuma akıcılığı, kelime tanıma, kelime hazinesi ve okuduğunu anlama stratejileri gibi beceri ve yeterliklere ihtiyaç duyulmaktadır. Bu süreçte basılı bir metin ya da kitap vardır. Öğrencilerin bu kitap ya da metinden yazıyı okuyarak ve görselleri yorumlayarak anlam kurması beklenir. Basılı materyallerden metin okuma ile doğrusal olmayan, çok sayıda metnin birbirine bağlantılı olduğu ve ses, video, görsel ve yazıların bir arada bulunduğu web sayfalarından metin okuma ve araştırmanın aynı olması beklenmemelidir.

Dijital ortamlarda okuma terimi, okuma eylemine yeni bir anlam katmakta ve öğrencilerin okuma başarısı için yeni öneriler getirmektedir. E-okuyucu ve tablet gibi 
dijital araçları kullanarak okuma ya da blog, wiki ve websitesi gibi dijital platformlarda okuma, çözümleme ve akıcılık gibi geleneksel okuma becerilerine ihtiyaç duymaktadır. $\mathrm{Bu}$ becerilerin yanı sira metinlerde gezinme, ses dinleme ya da metinlerle birlikte video izleme gibi beceriler de gerekmektedir (Hutchison \& Colwell, 2015). Dijital metinleri okumak için farklı beceriler, eğilimler ve stratejilere ihtiyaç vardır (Lankshear \& Knobel, 2011). Çevrim içi okuma ile ilgili yapılan ilk araştırmalardan birinde Schmardobler (2003) üst düzey beş beşinci sınıf öğrencisinin önemli fikirleri belirleme, anlamayı izleme, ön bilgileri aktifleştirme ve çıkarım yapma gibi geleneksel okuduğunu anlama stratejilerine yüzeysel inceleme, tarama, arama ve göz atma gibi okuma stratejilerini entegre ettiklerini bulmuşlardır.

Çevrim içi araştırma ve anlama küçük harflerle yeni okuryazarlığın incelediği önemli araştırma alanlarından birisidir. Bu bakış açısı çevrimiçi araştırma ve anlamayı problem temelli sorgulama süreci olarak görmekte ve bunun için yeni beceriler, stratejiler, eğilimler ve sosyal uygulamalara ihtiyaç duyulduğunu ileri sürmektedir (Leu ve diğerleri, 2013; Leu ve diğerleri, 2015). Leu ve diğerlerine (2013) göre çevrim içi araştırma ve anlamanın daha teknik bir tanımı şöyledir (s.1163-1164):

\begin{abstract}
Yeni okuryazarlık bakış açısından çevrimiçi araştırma ve anlama hızla değişen bilgi ve iletişim teknolojilerini başarılı bir şekilde kullanmak ve ona adapte olmak için gerekli olan beceri, strateji, eğilim ve sosyal uygulamaları ve kişisel ve mesleki yaşamın tüm alanlarını etkileyen ve sürekli meydana gelen bağlamları içermektedir. Çevrim içi araştırma ve anlama birçok okuma uygulamasına katılıyorken, bilgi ve metinlerin yapılandırıldığı öz yönetimli bir süreçtir. Bu süreçte önemli problemleri tanımlama, bilgiye ulaşma, bilgiyi eleştirel olarak değerlendirme, bilgiyi sentez etme ve bilgi ile iletişim kurma gibi uygulamalar yapılmaktadır. Çevrim içi araştırma ve anlama bireysel olarak gerçekleşebilir ama genellikle ortaklaşa gerçekleştiğinde güçlenmiş olacaktır.
\end{abstract}

Çevrim içi araştırma ve anlama yeni teknolojiler ve yeni sosyal uygulamalar gerektirmektedir (Leu ve diğerlerine, 2015). Günümüzde internet üzerinden çevrim içi okuduğunu anlamanın üst düzeyde gerçekleşmesi için öncelikle bireylerin araştıracağ1 konuya problem temelli yaklaşması ve sorular oluşturarak okumaya başlaması gerekmektedir. İkinci olarak öğrenciler yazdığı bu soruların cevaplarına ulaşmak için çeşitli araştırma stratejilerinde ustalaşmalıdırlar. Arama motorlarında nasıl araştırma yapılır? Araştırılan konu nasıl daraltılır ve özelleştirilir? Anahtar kelimeler kullanılarak nasıl araştırma yapılır? Bu sorular temelinde öğrencilerin bilgiye ulaşmak için çeşitli strateji ve becerilere sahip olması gerekmektedir. Üçüncü olarak öğrencilerin ulaştığı bilgiyi eleştirel bir süzgeçten geçirmesi ve doğruluğunu değerlendirmesi gerekmektedir. Günümüzde internette çok büyük miktarda bilgi vardır. Hangi siteler güvenilirdir? Bilginin güvenilirliğini nasıl test edebilirim? Bu sorular temelinde öğrencilerin eleştiren bir tutuma sahip olmaları gerekmektedir. Dördüncü olarak internette bilginin çok sayıda kaynağı vardır. Aynı anda birçok siteden aynı konu ile ilgili farkı bilgilere ulaşılabilir. İyi bir çevrim içi okuma için bu bilgilerin bütünleştirilmesi gerekmektedir. Tek bir kaynaktan bilgiye ulaşmak doğru değildir. Son olarak çevrim içi anlamanın en üst düzeyde gerçekleşmesi için, öğrencinin ulaştığı bilgilerle ilgili bir içerik oluşturması ve ulaştığ içeriği internet üzerinden çeşitli kişi ve topluluklarla paylaşması gerekmektedir. Yani çevrim içi okuduğunu anlama için etkileşim şarttır. Bu süreçler çevrim içi okumanın geleneksel okumadan yukarıda bahsedilen yönlerden bazı farklılıklarını yansitmaktadir. 
Çevrim içi okuduğunu anlama ile ilgili bazı kuramsal ve uygulamalı çalışmalar devam etmektedir. Çevrim içi araştırma ve anlama ile ilgili bu çalışmalardan ortaya çıkan bazı ortak özellikler şu şekildedir (Leu ve diğerleri, 2013):

- Çevrim içi araştırma ve anlama metni ve bilgiyi yapılandırmanın öz yönetimli bir sürecidir.

- Çevrim içi araştırma ve anlama sürecini tanımlamada beş basamak vardır: problemi tanımlama, bilgiye ulaşma, bilgiyi değerlendirme, bilgiyi sentez etme ve bilgiyle iletişim kurma.

- Çevrim içi araştırma ve anlama, çevrim dışı okuduğunu anlama ile eş yapılı değildir. Ek beceri ve stratejiler gerekir.

- Çevrim içi bağlamlar özellikle bazı okuma güçlüğü çeken öğrencileri destekleyicidir.

- Yetişkinler her zaman çevrim içi araştırma ve anlamada usta değildirler.

- İş birlikli çevrim içi okuma ve yazma uygulamaları anlama ve öğrenmeyi artırmış gibi görünmektedir.

Geleneksel basılı metinlere dayalı okuma ile çevrim içi araştırma ve anlama eş yapılı değildir. Bir başka ifade ile çevrim içi okuma ile geleneksel okuma sürecinde okurların işe koştukları bilişsel süreçler ve stratejiler arasında birçok farklılıklar vardır (Coiro \& Dobler, 2007). İlk olarak çevrim içi araştırma ve anlama çevrim içi bir araştırmanın yapıldığı problem çözme işidir. İkinci olarak çevrim içi araştırma ve anlama yazma ile sıkı bir şekilde iç içedir. Çünkü keşfetmeye çalıştığımız sorular hakkında daha fazla bilgi edinirken ve kendi yorumlarımızı katarken sürekli yazmak zorundayız. Üçüncü olarak çevrim içi araştırma ve anlama için internet tarayıcıları, arama motorları, bloglar, wikiler, e-postalar ve diğer birçok uygulamayı kullanmamız gerekmektedir. $\mathrm{Bu}$ nedenle bu teknolojilerin her biri ek beceri ve strateji gerektirmektedir. Son olarak çevrim içi araştırma ve anlama çevrim dişı okumadan daha fazla üst düzey düşünme gerektirmektedir (Leu ve diğerleri, 2015). Yapılan araştırmalar çevrim içi okuma ve çevrim dışı okuma arasında benzer özellikle olmasına rağmen, önemli farklılıklar olduğuna da işaret etmektedir (Afflerbach \& Cho, 2009, 2010; Castek, 2008; Coiro, 2011; Coiro \& Dobler, 2007; Esmer \& Ulusoy, 2015; Taboada \& Guthrie, 2006). Coiro ve Dobler (2007) yaptıkları bir çalışmada okuma becerisi yüksek 11 altıncı sınıf öğrencisi ile internet üzerinden okuduğunu anlamanın doğasını araştırmışlardır. Elde edilen bulgular basılı metinlerden okuma ile çevrim içi okumanın benzerliklere ve karmaşık düzeyde farklılıklara sahip olduğunu göstermiştir. Öğrenciler internetten okuma yaparken konu hakkında ön bilgilerinden ve basılı metinlerin yapısı ile ilgili bilgilerinden faydalanmışlardır. Ayrıca öğrenciler sık sık çıkarım yapma stratejilerini işe koşmuşlar ve hedef belirleme, tahmin, izleme ve değerlendirme gibi geleneksel öz düzenleyici okuma stratejilerini kullanmışlardır. Bunlara ek olarak öğrenciler çevrim içi okuma yaparken, bilgilendirici websitesi yapısı ile web temelli arama motorları hakkında iki ek ön bilgi kaynağını kullanmışlardır. Çok tabakalı internet metinleri sayesinde internet, yüksek çıkarımsal anlamaya yol açmıştır. Öğrenciler sık sık web temelli okuma bağlamlarına özgü yeni okuma eylemleri ile içi içe geçmiş bilişsel öz düzenleyici okuma sürecine katılmışlardır.

Çevrim içi araştırma ve anlama bir konu hakkında basit bir şekilde araştırma yapılarak bilgiye ulaşılan bireysel bir süreç değil; doğası gereği iş birlikli ve sosyaldir 
(Leu ve diğerleri, 2011). Çünkü internet bireyler, gruplar ve toplumlar arasındaki iletişimi artırmıştır. Bilgiye ulaşmak ve bilgiyi paylaşmak için blog, wiki ve twitter gibi çok sayıda sosyal uygulama vardır. Son zamanlarda çevrim içi okumanın ve okuduğunu anlamanın iş birlikli doğasını keşfetmeye yönelik araştırmalar ortaya çıkmaktadır (Chen \& Chen, 2014; Coiro, Sekeres, Castek, \& Guzniczak, 2014; Kiili, Laurinen, Marttunen \& Leu, 2012; Passig \& Maidel-Kravetsky, 2016). Kiili ve diğerleri (2012) yaptıkları çalışmada lise öğrencilerinin çevrim içi iş birlikli bir okuma ortamında bilgiyi ve anlamı nasıl yapılandırdıklarını incelemişlerdir. Öğrencilerden eşli olarak tartışmalı bir konu hakkında bir makale yazmaları istenmiştir. Kaynaklara internetten ulaşmışlar ve birlikte bir kompozisyon yazmışlardır. Elde edilen bulgulara göre öğrencilerin yazma etkinlikleri boyunca zamanın \%88'ini içerik oluşturma ve bilgiye ulaşma oluşturmuştur. Zamanın \%12'si de bilgiyi değerlendirme, izleme, düzenleme etkinlileri ile görev diş1 uygulamalara ayrılmıştır. Araştırma, çevrim içi okuduğunu anlama ve bilginin eşler tarafından yapılandırılmasına katkıda bulunan iş birlikli ve sosyal bir uygulama olduğunu ortaya koymuştur. Öğrencilerin iş birlikli okuma sürecinde en çok kullandıkları stratejiler bilgiye ulaşma, argüman geliştirme, çıkarım yapma, ön bilgileri kullanma ve soru oluşturmadır. Chen ve Chen (2014) beşinci sınıf öğrencileri ile yaptıkları bir çalışmada okuma becerilerini geliştirmek için iş birlikli dijital bir okuma çevresi geliştirmişlerdir. Deney grubu öğrencileri bu iş birlikli dijital çevrede okuma çalışmaları gerçekleştirirken, kontrol grubu öğrencileri geleneksel yüz yüze sınıf ortamında okuma çalışmaları gerçekleştirmişlerdir. Araştırmadan elde edilen sonuçlara göre deney grubu öğrencileri okuduğunu anlama ve okuma stratejileri kullanımında anlamlı derecede daha yüksek puan elde etmişlerdir. Ayrıca araştırmacılar, iş birlikli dijital okumanın öğrenciler arasındaki etkileşimli tartışmaları ve yüksek düzeyli düşünmeyi geliştirebileceği ve gereksiz tartışmalara harcanan zamanı azaltabileceğini ortaya koymuşlardır.

Basılı materyallere dayalı okuma ve yazma güçlükleri günümüz okullarının en önemli problemlerinden birisidir. Ancak çevrim içi olarak internet ortamında bu öğrencilerin araştırma ve okuma davranışlarının nasıl olduğu önemli bir araştırma alanıdır. Yapılan çeşitli araştırmalar geleneksel basılı metinlere dayalı okuma güçlüğü çeken öğrencilerin çevrim içi ortamlarda daha fazla katılım gösterdiklerini ve çevrimi içi araştırma ve anlamada daha başarılı oldukların göstermektedir (Castek, Zawilinski, McVerry, O ' Byrne, \& Leu, 2011; Henry, Castek, O’Byrne, \& Zawilinski, 2012). Çevrim içi ortamlar okuma ve yazma güçlügü çeken öğrencileri destekleyici olabilir. İlk olarak çevrim içi bağlamlarda metin üniteleri daha kısadır. Daha kısa metin ünitelerini işlemek okuma güçlüğü çeken öğrenciler için daha kolaydır. Çevrim içi okurlar bilgi edinmek için kendi yolunu seçmektedir. Bilgiye ulaşmak için tek bir geçerli yol yoktur. $\mathrm{Bu}$ durum öğrencinin katılımını artırır. Çevrim içi bağlamlar çok biçimli ögeleri (ses, video, yazı ve görsel) içerisinde barındırmaktadır. Son olarak web sayfası gerçekten de grafiksel bir görseldir. Bilginin grafiksel sunumu okuma güçlüğü çeken çocuklar için daha kolaydır (Leu ve diğerleri, 2012). Castek ve diğerleri (2011) yaptıkları bir çalışmada geleneksel basılı metinleri okumada güçlük çeken dört öğrencinin çevrim içi araştırma ve anlama davranışlarını incelemişlerdir. Elde edilen bulgular okuma güçlügü çeken bu öğrencilerin çevrim içi okuma deneyimleri boyunca önemli araştırma becerilerine sahip olduklarını, çevrim içi iletişim kurmada oldukça etkili olduklarını, öğrencilerin okuma becerilerinin grafiksel ve çoklu ortam araçları sayesinde 
desteklendiğini ve yüksek düzeyde anlamayı izleme davranışı gösterdiklerini ortaya koymuştur. Bu bulgu çevrim içi okuma için öncelikle geleneksel basılı metinlere dayalı okumanın geliştirilmesi gerektiği fikrini yıkabilir.

\section{Teknoloji ve Çevrim İçi Yazma Üzerine Yapılan Araştırmalar}

Yazma alanyazınına bakıldığında geleneksel anlamda yazma araştırmaları ve öğretimi güzel yazma, kelimeleri doğru yazma, cümle ve paragraf yapılandırma, yazma stratejilerinin öğretimi ve süreç temelli yazma gibi beceri ve süreçlere odaklanmaktadır. $\mathrm{Bu}$ araştırmalar ve uygulamalar bilişsel, motivasyonel ve sosyokültürel kuram ve modellere dayalı olarak gerçekleştirilmektedir. Son yıllarda bilgi ve iletişim teknolojilerinin yaygınlaşmasıyla birlikte hipermetin, çevrim içi okuma ve yazma, kelime işlemci ile yazma, internet ve çok biçimli metin gibi kavram ve uygulamalar yazar olmanın anlamını ve yazma öğretiminin doğasını değişmeye zorlamaktadır. Bu nedenle kağıt kaleme dayalı tek başına geleneksel yazma ve sınıf ortamında paylaşma düşüncesi günümüz dünyasına uymamaktadır. Öğrenciler geleneksel yazma becerilerinin tamamlayıcısı olarak çevrimi içi metin oluşturma, çoklu ortamda iş birlikli yazma, çok biçimli içerik oluşturma, internet üzerinde çok sayıda kişi ile yazılarını paylaşma ve kelime işlemci kullanarak yazmada ustalaşarak çevrim içi anlam ve içerik oluşturmayı öğrenmelidirler.

Günümüzde öğrenciler dijital teknolojiler sayesinde wiki mesajları, blog gönderileri, podcast dosyaları, sosyal medya mesajları ve dijital kitaplar gibi çeşitli dijital biçimlerde yazmaktadırlar. $\mathrm{Bu}$ yeni biçimler sayesinde öğrenciler yeni yazma amaçları belirleyebilirler ve yeni hedef kitleler için yazabilirler. Dijital teknolojilerin yazma öğretimindeki etkilerinden birisi de öğrenciler için paylaşma ve iş birliğini güçlendirmesidir. Bloglar, wikiler ya da Google doküman gibi dijital sosyal bağlamlar, öğrencilerin ortak metinler üretmelerini ve bilgiyi paylaşmalarını kolaylaştırmaktadır (Hutchison \& Colwell, 2015).

Yazma öğretiminde teknoloji entegrasyonu konusunu tek bir bakış açısı ya da kuramsal yaklaşımla ele almak oldukça güçtür. Teknolojiyi yazma öğretimine entegre etmeye çalışan araştırmalara bakıldığında birçok kuramsal bakış açısı, araştırma metodolojisi ve sosyal uygulamadan faydalanıldığı görülmektedir. Yazmada teknoloji kullanımı üzerine yapılan araştırmaların dayandığı kuramsal çerçevelerden bazıları bilişsel kuram (Berninger ve diğerleri, 2002), küçük harflerle yeni okuryazarlık kuramı (Leu ve diğerleri, 2016), yazmada çok biçimlilik (multimodality) kuramı (Kress, 2003; Walsh, 2010), sosyokültürel kuram (Vygotsky, 1978) ve aktivite kuramıdır (Engstrom, 1999).

Teknoloji ve yazma öğretimi ile ilgili geleneksel olarak yapılan tartışmalardan birisi kağıt kalemle yazma ve tablet ya da klavye ile yazmadan hangisinin daha etkili olduğu ile ilgilidir. Bazı araştırmalar geleneksel olarak nicel bakış açısından kağıt kaleme dayalı yazma öğretimi ve tablet ya da klavye ile yazma öğretiminin öğrencilerin yazılarındaki kelime sayısı, hızı ve niteliği gibi değişkenler üzerindeki etkisini incelemiştir. Geleneksel yazma becerilerinin gelişiminde klavye ya da tablet gibi teknolojilerin destekleyici bir araç olarak kullanılabileceği ortaya konmasına rağmen, nicel ve bilişsel bakış açısından kelime işlemcinin mi yoksa kâğıt kalemin mi daha etkili olduğu hakkında hâlâ tutarsız bulgular vardır (Berninger, Abbott, Augsburger, \& Garcia, 2009; Connelly, Gee, \& Walsh 2007; Crook \& Bennett, 2007; Sessions, Ok 
Kang, \& Womack, 2016; Wollscheid, Sjaastad, Tømte, \& Løver 2016; Wollscheid, Sjaastad, \& Tømte, 2016). Wollscheid ve diğerleri (2016) yaptıkları son bir çalışmada ilkokul düzeyinde tablet bilgisayarlar ve kağıt kalemle yazmayı karşılaştıran araştırmaları incelemişlerdir. Yazma ve teknoloji üzerine yapılan araştırmalar bilişsel kuramlar, sinirbilim ve öğrenme ve sosyokültürel kuramlar başlıkları altında toplanmıştır. $\mathrm{Bu}$ inceleme üç farklı bakış açısını kullanan çalışmalardan elde edilen bulguların baştanbaşa tutarsız olduğunu göstermiştir. Ne kâğıt kalem kullanarak yazma ne de tabletle yazma üzerine herhangi bir sonuç çıkarmaya olanak yoktur. Bilişsel kuramın bakış açısını kullanan çalışmaların özellikle kâğıt kalemle yazmanın faydalarına yönelik bulgularının olduğu görülmektedir. Ancak sosyokültürel ve yeni okuryazarlık bakış açılarını kullanan son çalışmalar ise dijital yazma araçları lehine sonuçlara ulaşmaktadır.

Bazı araştırmalar sosyokültürel veya yeni okuryazarlık kuramlarına dayalı olarak dijital yazma uygulamalarının yazma sürecinin ve öğretiminin doğasına, yeni okuryazarlık becerilerine ve dijital yazar olmanın anlamına olan etkisini nitel bakış açısından keşfetmeye çalışmaktadır. Bu kuramsal alt yapılara dayalı olarak yazma öğretimde dijital öyküleme (Vasudevan, Schultz, \& Bateman, 2010; Yamaç \& Ulusoy, 2016), bloglarda yazma (Jones \& Rice, 2017; Mcgrail \& Davis, 2011), yazmada wiki kullanımı (Pifarre \& Li, 2009), sosyal medyada iş birlikli yazma (Liu, Liu, Chen, Lin, \& Chen, 2011), sanal dünyada okuma yazma eğitimi (Merchant, 2009) ve dijital oyunlarla yazma (Howell, 2017) gibi çeşitli sosyal uygulamalar geliştirilmeye çalışılmaktadır.

Sosyokültürel ve yeni okuryazarlık bakış açısına dayalı olarak yapılan çalışmalar dijital ortamda yazmanın öğrencilerin motivasyonunu artırdığını (Pruden, Kerkhoff, Spires, \& Lester, 2017; McGrail \& Davis, 2011), yeni okuryazarlık ve hedef kitle algısını genişlettiğini (McGrail \& Davis, 2011; Yamaç \& Ulusoy, 2016), çok biçimli metinler sayesinde kompozisyon algısını değiştirdiğini (Vasudevan ve diğerleri, 2010), öğrenciler arasındaki etkileşimi artırarak iş birliğini güçlendirdiğini (Handsfield, Dean, \& Cielocha, 2009; Sessions ve diğerleri, 2016; Zawilinski, 2012) ve yazma sürecini geliştirdiğini (Bogard \& McMackin, 2012; Sylvester \& Greenidge, 2009) ortaya koymuştur. Pruden ve diğerleri (2017) Narrative Theatre isimli bir hikâye temelli dijital öğrenme çevresinin yazma güçlüğü çeken 3 erkek öğrencinin yazma süreçlerini nasıl etkilediğini araştırmışlardır. Narrative theatre'da öğrenciler için sesli yönergeler, şablon, hazır ortamlar, karakterler ahlaki değerler ve nesneler ve öğrenme desteği yer almaktadır. Araştırmadan elde edilen bulgular öğrencilere seçme hakkı verildiğinde yazmaya daha fazla ilgili olduklarını, Narrative theatre yazma modülünün yazma sürecinde öğrenme desteği sağlayan yapılandırılmış bir çevre olduğunu ve öğrencilerin yazma öz yeterliğini artırdığı ortaya koymuştur. Cordero ve diğerleri (2015) üçüncü sınıf öğrencilerinin okuma ve yazma becerilerini geliştirmek ve yazma sürecine entegre etmek için Oku-Yarat-Paylaş adında bir tablet uygulaması geliştirmişlerdir. Bu uygulama sayesinde öğrenciler bir oyun mekanizması sayesinde çok biçimli bir hikâyeyi eşli olarak yapılandırmışlardır. Araştırmadan elde edilen bulgular oyun mekanizmalarının öyküleyici anlatımı destekleyerek çok biçimli metin oluşturmada umut vermiştir. Ayrıca araştırma etkileşimli ve eşli çalışmayı destekleyen teknolojik araçların ilkokul öğrencilerinin okuma ve yazma becerileri arasında bir köprü görevi gördügünü göstermiştir. 


\section{Dijital Bölünme ve Yeni Okuryazarlık}

Dijital bölünme kavramı bilgi ve iletişim teknolojilerini kullanma ve bilgi iletişim teknolojilerine ulaşma bakımından üst ve alt sosyoekonomik düzeyde yer alan bireyler arasındaki farkı ifade etmek için kullanılmaktadır (Organisation for Economic Co-operation and Development [OECD], 2001; Van Dijk, 2006). Geleneksel anlamda basılı materyallerde okuma yazma becerileri açısından farklı sosyoekonomik düzeyden gelen öğrenciler arasında üst sosyoekonomik düzeydeki öğrenciler lehine bir okuma açığı olduğu çeşitli araştırmalarda vurgulanmaktadır (Reardon \& Galindo, 2009; Reardon, 2011). Üst ve alt sosyoekonomik düzeyden gelen öğrenciler arasında okuma açığını gidermek için karar alıcılara büyük görev düşmektedir. Özellikle dezavantajlı öğrencilerin okuryazarlık becerilerinin okula başlamadan önce giderilmesi için çeşitli politikalara ihtiyaç olduğu uzun yıllardır tartışılmaktadır. Ancak bu geleneksel basılı materyallere dayalı okuma açı̆̆ı son yıllarda çevrim içi okuma ve yazmanın yaygınlaşmasıyla birlikte farklı bir boyuta taşınmıştır. Çünkü öğrencilerin sosyoekonomik düzeyi onların internet olanaklarına ulaşım ve interneti kullanma firsatlarını da etkileyebilmektedir.

Çeşitli araştırmalar farklı sosyoekonomik düzeyde yer alan öğrencilerin ev ve okul ortamlarında bilgisayar, internet ve teknoloji kullanımlarının farklılaştığını göstermektedir (Leu, Forzani, Rhoads, Maykel, Kennedy, \& Timbrell, 2014; Li \& Ranieri, 2013). Bazı araştırmalar da öğrencilerin çevrim içi araştırma ve anlama puanlarının sosyoekonomik düzeye göre farklılaştığını vurgulamaktadır (Henry, 2007; Leu ve diğerleri, 2014). Henry (2007) yaptığı doktora tezinde ayrıcalıklı bölgelerdeki öğrencilerin çevrim içi okuduğunu anlama puanlarının dezavantajlı bölgelerdeki öğrencilere göre anlamlı derecede daha yüksek olduğunu ve internete ulaşım olanakları ve internet kullanımının çevrim içi okumayı yordayan iki önemli değişken olduğunu göstermiştir. Leu ve diğerleri (2014) yaptıkları bir çalışmada üst sosyoekonomik düzeydeki ve alt sosyoekonomik düzeydeki öğrencilerin geleneksel okuryazarlık becerileri ile yeni okuryazarlık becerilerini karşılaştırmışlardır. Öğrencilerin geleneksel okuyazarlık becerileri ve ön bilgileri kontrol altına alındığında, yeni okuryazarlık becerileri açısından üst sosyoekonomik düzeyde yer alan öğrencilerin lehine anlamlı bir farklılık olduğu gözlemlenmiştir. Ayrıca araştırmanın bir diğer bulgusu, üst sosyoekonomik düzeydeki öğrencilerin evlerinde daha fazla internet erişimine sahip olmaları ve daha fazla internet kullanmaya özendirilmeleridir. Leu ve Maykel (2016)'e göre üst ve alt sosyoekonomik düzeydeki öğrencilerin yeni okuryazarlık becerileri açısından oluşan bu açık geleneksel basılı materyallere dayalı okumadan bağımsızdır ve sadece bir sınıf düzeyine değil birçok değişkene bağlıdır. Çocuklardaki çevrim içi okuma ve anlama becerilerinin gelişimi, toplumdaki her bir bireye bilgi ve iletişim çağında yaşam fırsatı yaratmanın temeli oluşturmaktadır.

\section{Sonuç ve Öneriler}

$\mathrm{Bu}$ çalışmanın amacı günümüz sosyal, ekonomik, kültürel ve teknoloji bağlamında okuryazarlığın değişen doğasını inceleyen kuramsal ve uygulamalı çalışmaları gözden geçirmek ve karar alıcılar, araştırmacılar ve öğretmenler için çeşitli öneriler getirmekti. Bu amaç doğrultusunda iki düzeyli yeni okuryazarlık kuramı incelenmiş, etkili bir okuryazarlık eğitimi için öğretim programları ve sınıflara bilgi ve iletişim teknolojilerinin entegrasyonu irdelenmiş, çevrimi içi okuma ve yazma ile ilgili 
araştırmalar gözden geçirilmiş ve dijital bölünme kavramı ele alınmıştır. Sonuç olarak okuryazarlık teknolojik, sosyal ve kültürel dönüşümler sonucunda sürekli değişim halinde olan bir olgudur. 20-30 yıl öncesinin dünyasında başarılı olmak için yeterli olan beceriler artık günümüzde yeterli değildir. Günümüzde okuryazar olmak için ek beceri, strateji ve eğilimler gerekmektedir. Bu doğrultuda öğretim programları ve sinıf ortamları yeniden ele alınmalıdır. 20-30 yıl öncesinin okuma yazma uygulamaları günümüz dünyasına öğrencileri hazırlamak için yeterli değildir. $\mathrm{Bu}$ konuda öğretmenlere büyük sorumluluk düşmektedir. Öğrencilerin önemli sorular belirlemeleri, bilgiye ulaşmaları, bilgiyi değerlendirmeleri, çeşitli kaynaklardan bilgileri sentez etmeleri ve çevrim içi anlam ve içerik oluşturmaları için öğretmenlerin çeşitli bilgi ve iletişim teknolojilerini okuryazarlık eğitimi derslerine entegre etmeleri gerekmektedir. Çünkü geleneksel basılı materyallerle okuma ve kağıt kalem kullanarak yazma, çevrim içi okuma ve yazma ile eş yapılı değildir. Son olarak farklı sosyoekonomik düzeyde yer alan öğrencilerin bilgi ve iletişim teknolojilerine ulaşım ve kullanım fırsatları aynı olmadığı için alt ve üst sosyo ekonomik düzeyde yer alan öğrenciler arasında yeni okuryazarlık becerileri açısından dijital bir bölünme yaşanmaktadır. Tüm bu sonuçlar doğrultusunda karar alıcılar, araştırmacılar ve öğretmenler için şu öneriler getirilmiştir:

\section{Karar Alıcılar İçin Öneriler}

Günümüz bilgi çağında öğrencileri iş yaşamına ve akademik yaşama yeterli düzeyde hazırlayabilmek için onların okuma ve yazmada yeni strateji, beceri ve eğilimlerle donatılması gerekmektedir (Leu ve diğerleri, 2015). Bu nedenle yeni teknolojiler ve çevrim içi okuma ve yazma becerileri, stratejileri, uygulamaları ve eğilimleri öğretim programına entegre edilmelidir (Uluslararası Okuma Derneği, 2009). Amerika Birleşik Devletleri, Kanada ve Avustralya gibi devletlerin çevrim içi bilgi çağında, çalışma ve iş yaşamına öğrencileri hazırlamak için öğretim programlarına ve eğitsel standartlarına yeni okuryazarlık uygulamalarını entegre eden bazı girişimler başlattıkları görülmektedir (Leu ve diğerleri, 2011; Leu ve diğerleri, 2015). Türkiye'de 2017 yılında yürürlüğe giren 1-8 sinıflar Türkçe öğretim programı göz önüne alındığında, programda dijital yetkinliğin temel becerilerden biri olarak görüldüğü belirtilmektedir. Ancak ilk dört sınıfta çevrim içi okuma ve yazma ile ilgili kazanımlara hemen hemen hiç yer verilmediği görülmektedir. 4.-8. sınıflar göz önüne alındığında çevrim içi yazma ile ilgili sadece yazdıklarını sosyal medya ortamlarında paylaşma kazanımı yer almaktadır. Çevrim içi okuma ile ilgili ise bilgi kaynaklarının güvenirliğini sorgulama ve bilgi kaynaklarını kullanma kazanımlarına yer verilmiştir (MEB, 2017). Ekrandan okumanın ve bilgi ve iletişim teknolojilerinin bu denli hayatımızı çevrelediği bir çağda (Rideout ve diğerleri, 2010; TUİK, 2016) çevrim içi araştırma ve anlama ile çevrim içi yazmaya Türkçe öğretim programında çok az yer verildiği, okuryazarlığın çok büyük bir oranda geleneksel basılı okuma yazma çalışmalarına dayalı olarak ele alındığı sonucu çıkmaktadır. Bu durum Türk çocukların günümüz yeni okuryazarlık becerileri açısından endişe verici olabilir. Türkçe öğretim programlarına çevrim içi soru yazma, bilgiye ulaşma, bilgiyi eleştirel olarak değerlendirme, bilgiyi sentez etme, çevrim içi okuma stratejilerini uygulama, çeşitli sosyal uygulamaları (blog, wiki ve sosyal medya vb.) kullanma, çevrim içi araştırma ve anlama becerilerini değerlendirme, çok biçimli metin oluşturma, kelime işlemcilerle yazı yazma ve çok biçimli metin oluşturma gibi çeşitli uygulama, beceri ve stratejilerin entegre edilmesi gerçeğine yüz çevrilmemelidir. 
Günümüz dünyasında mesleki ve akademik başarı için, geleneksel basılı okuma yazma becerileri ile çevrim içi araştırma ve anlama becerileri en temel araçlardır. Dezavantajlı öğrencilerin geleneksel basılı okuma yazma becerileri açısından küçük yaşlardan itibaren diğer öğrencilerin gerisinde kaldığ 1 ve bir okuma yazma açığı oluştuğu bilinen bir gerçektir (Reardon, 2011). Ancak günümüz bilgi ve iletişim teknolojileri, dezavantajlı öğrencilerle diğer öğrenciler arasında bir başka okuryazarlık açığına sebep olmaktadır (Leu ve diğerleri, 2015). Çevrim içi araştırma ve anlama geleneksel basılı okuma yazma becerileri ile eş yapılı değildir ve düşük sosyoekonomik düzeydeki öğrenciler bilgi ve iletişim teknolojilerini kullanma bakımından daha az firsata sahiptirler (Henry, 2007; Leu ve diğerleri, 2014; Leu ve diğerleri, 2015; Leu \& Meykel, 2016). Dezavantajlı bölgelerdeki çocuklar ile üst sosyoekonomik düzeydeki çocuklar arasında küçük yaşlardan itibaren yeni okuryazarlık becerileri açısından bir açık oluşmaktadır. Bu açık dezavantajlı çocukların gelecekteki akademik başarıları ve iş yaşamlarında büyük bir dezavantaj yaratabilir. Bu nedenle küçük yaşlardan itibaren dezavantajlı öğrencilerle diğer öğrenciler arasındaki hem geleneksel okuryazarlık hem de yeni okuryazarlık açısından var olan açığı kapatmaya yönelik siyasi girişimlere ihtiyaç vardır.

\section{Araştırmacılar İçin Öneriler}

Yeni okuryazarlık bakış açısından araştırmalar şu iki soruya yanıt aramalıdır (Leu ve diğerleri, 2013):

- Yeni okuryazarlığın elde edilmesi için önemli olan sosyal uygulamalar, stratejiler, eğilimler ve beceriler nelerdir?

- Yeni okuryazarlığın bu boyutlarını gerçek ve sanal öğrenme bağlamlarından en iyi nasıl destekleyebiliriz?

Geleneksel anlamda okuma araştırmacıları öğrencilerin basılı materyalleri okumaları ve anlamalarında önemli olan sesbilimsel farkındalık, kelime tanıma, okuma akıcılığ1, okuduğunu anlama ve kelime hazinesi gibi bilgi ve becerilerin doğasını keşfetmeye yönelik çalışmaktadırlar. Çevrim içi okuma sürecinde geleneksel okuma becerilerinin önemi devam etmesine rağmen, çevrim içi araştırma ve anlama için yeterli olmayabilir. Çevrim içi anlama ve araştırmada metinler doğrusal değildir, sosyal bağlam farklıdır ve anlam ses, video, yazı ve görsel gibi birçok çoklu ortam ögesi sayesinde elde edilmektedir. Bu nedenle çevrim içi araştırma ve anlama sürecindeki beceriler, eğilimler ve stratejiler keşfedilmelidir. Özellikle ilkokul düzeyinde okuduğunu anlama sürecinde basılı materyallere dayalı okuma ve çevrim içi anlama ve araştırma arasındaki farklılıklar üzerine daha fazla araştırma yapılmalıdır. Çevrim içi anlama ve araştırma sürecinde öğrencilerin araştıracağı konu ile ilgili soru yazma, bilgiye ulaşma, ulaşılan bilgileri eleştirel süzgeçten geçirme, bilgileri sentezleme ve içerik oluşturma süreçlerini keşfetmeye yönelik araştırmalara ihtiyaç vardır.

Bilgi ve iletişim teknolojilerinin gelişmesiyle son y1llarda öğrencilerin dijital okuma yapmaları ve metne tepki vermeleri, dijital kitap oluşturmaları ve yayınlamaları, çoklu ortamda içerik oluşturmaları, iş birlikli yazılar yazmaları, çoklu ortamda tartışma ve paylaşımda bulunmaları, grafik düzenleyiciler oluşturmaları ve çok biçimli metinler oluşturmaları için birçok uygulama ve internet sitesi ortaya çıkmıştır. Bookcreator, evernote, blogger, twitter, Google dokümanlar ve wikispace bunlardan bazılarıdır. Öğrencilerin geleneksel okuma ve yazma becerilerinin yanı sıra yeni okuryazarlık 
becerilerini de geliştirmek için bu uygulama ve internet sitelerinin okuma yazma eğitimine entegre edilmeleri gerekmektedir. $\mathrm{Bu}$ nedenle tablet bilgisayarlar ya da bilgisayarlar üzerinden bu uygulamaları okuma çemberleri, eşli okuma, rehberli okuma, okuduğunu anlama stratejileri ve okuma akıcılığını geliştirme yöntemleri ile okuma öğretimine entegre eden çeşitli araştırmalara ihtiyaç vardır.

Gelişen bilgi ve iletişim teknolojileri ile birlikte çevrim içi okuma ve yazmanın doğası değişmeye devam ederken, kelime tanıma, okuma akıcılığı ve okuduğunu anlama gibi geleneksel kağıt kaleme dayalı okuryazarlık becerilerini değerlendiren araçlar yeni okuryazarlık için yeterli olmamaktadır. Yeni okuryazarlık yeni beceriler, stratejiler ve eğilimler gerektirmektedir. Ancak öğretimi bilgilendirmek için ve öğrencileri bilgi ve iletişim çağına daha iyi hazırlamak için yeni okuryazarlığın geçerli, güvenilir ve pratik değerlendirme araçları yoktur (Leu ve diğerleri, 2013). Yeni okuryazarlığı değerlendirmeye yönelik geliştirilen nadir çalışmalardan birisi Çevrim İçi Araştırma ve Anlamayı Değerlendirme (ÇAAD) projesidir (Leu, Kulikowich, Sedransk, \& Coiro, 2009-2014). ÇAAD değerlendirme aracı öğrencilerin çevrim içi araştırma ve anlama yeteneğini ölçmek için geliştirilmiştir. Öğrencilerden Fen dersleri ile ilgili sunulan problemleri çözmek için çevrim içi bilgileri ve çeşitli internet araçlarını kullanmaları istenmektedir. Öğrencilerin çevrim içi araştırma ve anlama süreci bilgiye ulaşma, bilgiyi eleştirel değerlendirme, bilgiyi sentez etme ve bilgiyle çevrim içi iletişim kurma alt boyutlarında puanlanmaktadır (Leu ve diğerleri, 2015). Sormunen ve arkadaşları (2018) yaptıkları bir araştırmada, öğrencilerin çevrim içi araştırma yeterliklerini değerlendirmek için kullanılabilecek NEURONE (http://www.neurone.info/) isimli bir web tabanlı sistem geliştirmişlerdir. Bu sistem üzerinden öğretmenler öğrencilerine araştırma görevleri vermektedir. Öğrenciler de bilgiye ulaşma, önemli fikirleri belirleme, bilgiyi değerlendirme ve sentez etme aşamalarından geçerek araştırma yapmaktadır. Bu tür araştırmalar var olmakla birlikte öğrencilerin çevrim içi okuma ve yazma becerilerini değerlendirmeye yönelik daha fazla değerlendirme aracı geliştirilmelidir.

Gelişen bilgi ve iletişim teknolojileri ile birlikte dijital kitap oluşturma, dijital okuma ve yazma, çok biçimli metin oluşturma, blog ve wiki gibi birçok uygulama, program ve internet sitesi ortaya çıkarken, bu araçların öğretmenler tarafından okuma ve yazma eğitimine nasıl ve ne kadar entegre edildiği önemli bir soru işaretidir. Uluslararası Okuma Derneği (2009) özellikle yarının okuryazarlığına öğrencileri hazırlamak için yeni teknolojilerin öğretim programlarına entegre edilmeleri gerektiğini vurgulamaktadır. Amerika ve Güney Kore gibi bazı ülkelerde öğretmenlerin okuma ve yazma eğitiminde teknolojiyi ne derece entegre ettiklerine (Hutchison \& Reinking, 2011; Pang ve diğerleri, 2015) ve okuma yazma eğitiminde teknoloji kullanım algılarına (O’Neal ve diğerleri, 2017) yönelik araştırmalar yapılmaktadır. Özellikle Türkiye bağlamında ilkokuldan liseye kadar okuma yazma eğitimcilerinin teknoloji entegrasyonları ve teknolojiye yönelik algıları araştırılması gereken konulardan birisidir.

Yeni okuryazarlık araştırmacılarının üzerinde durması gereken bir diğer araştırma alanı okuma ve yazma güçlükleridir. Geleneksel anlamda basılı materyalleri okumada güçlük çeken öğrencilerin dijital ortamda okuma yazma davranışları ve düzeyleri farklı olabilmektedir (Castek ve diğerleri, 2011; Henry ve diğerleri, 2012; Vasudevan ve diğerleri, 2010). Geleneksel anlamda okuma yazma güçlüğü çeken 
öğrenciler çevrim içi bağlamlarda daha yüksek performans gösterebilmektedir. Bu nedenle çevrim içi bağlamlarda okuma yazma güçlüğü çeken öğrencilerin okuma davranışları, okuma becerileri ve okuma yazma güçlügünün giderilmesine yönelik daha fazla araştırma yapılmalıdır. Özellikle okuma yazma güçlüğü çeken öğrencilerin kelime tanıma, okuma hızı, okuduğunu anlama ve çevrim içi okuma ve yazma becerilerini geliştirmeye yönelik çeşitli yazı, ses, görsel ve video gibi çoklu ortam ögelerini içeren programlar ve uygulamalar geliştirilebilir.

Geleneksel anlamda yazma becerileri kâğıt kalem kullanarak güzel yazma, kelimeleri doğru yazma, cümle, paragraf ve metin oluşturma ve yazma süreci ve stratejileri ile tanımlanmakta ve açıklanmaktadır (Berninger, Abbott, Augsburger, \& Garcia, 2009). Ancak internetin yazma süreci ve doğasında derin değişiklikler yaptığ göz önüne alındığında (Leu ve diğerleri, 2016), çevrim içi yazma süreci, çevrim içi anlam oluşturma, tabletlerle yazma ve çevrim içi yazmayı değerlendirme araçlarına yönelik daha fazla araştırma yapılmalıdır. Özellikle öğrencilerin yazma sürecini ve stratejilerini kullanabilecekleri, çevrim içi okuma ile entegre edilmiş, öğrencilerin dijital çevrede etkileşim ve iş birliğini sağlayan ve geniş hedef kitleleri ile yazıların paylaşabilecekleri hem bilişsel hem de yeni okuryazarlık bakış açılarına dayanan dijital yazma çevreleri geliştirilmelidir.

Alt sosyoekonomik düzeyde yer alan öğrenciler iki kat dezavantaj yaşamaktadırlar. Onlar hem evde internet ulaşımına sahip değildirler. Hem de okulların teknoloji alt yapısı kötüdür (Leu ve diğerleri, 2013). Sosyoekonomik düzeyi düşük bölgelerdeki öğrencilerle sosyoekonomik düzeyi yüksek bölgelerdeki öğrencilerin yeni okuryazarlık becerileri arasındaki farklılıkları incelemeye yönelik daha fazla çalışma yapilmalidir.

\section{Öğretmenler İçin Öneriler}

Eğitimciler olarak bilgi iletişim teknolojilerini Türkçe derslerinde ve diğer derslerde çevrim içi okuma ve yazma öğretiminde tüm öğrenciler için daha fazla entegre etmemiz gerekmektedir (Castek ve diğerleri, 2011). Aşağıda öğretmenler için bazı öneriler getirilmiştir:

- Öğrencilerin yeni okuryazarlık becerini geliştirmeye mümkün olduğu kadar erken yaşlarda başlamak gerekmektedir (Leu ve diğerleri, 2015).

- Okuma ve yazma güçlügü çeken öğrenciler için tabletler üzerinden kelime işlemcilerle okuma ve yazma faaliyetleri yaptırılabilir. Tabletler üzerinde okuma ve yazma faaliyetleri öğrenciler için eğlenceli ve kolaylaştırıcı olabilir.

- Öğrencilerin kişisel bloglar hazırlamalarına destek olmak gerekmektedir. Bloglar öğrencilerin dijital bir portfolyosu olabilir. Öğrenciler bloglarda oluşturduğu çeşitli görsel, yazı ya da videoları paylaşabilir ya da öğrenciler birbirlerinin yazılarını değerlendirebilir. Ayrıca öğretmen bir sınıf bloğu kurarak çeşitli okuma yazma faaliyetlerini bu blogdan paylaşabilir.

- Öğrencilere çeşitli arama motorları kullanarak bilgi arama yöntemleri ve stratejileri (anahtar kelimeler, araştırma vb.), bilginin doğruluğunu değerlendirme yöntemleri ve güvenilir sitelere nasıl ulaşılabileceği öğrenme desteği sağlayarak öğretilmelidir.

- Öğrencilerle çevrim içi iletişim kurmak, onlara çevrim içi ödev vermek ve toplamak, onlarla dosya paylaşmak ve ebeveynlerle daha hızlı iletişim 
kurabilmek için Google grup, Google drive, Google sınıf, Edmudo ve Beyazpano gibi siteler ve uygulamalarla sanal sınıflar oluşturulabilir.

- Evernote ve Diigo gibi uygulama ve siteler öğrencilerin PDF dosyalarını okuma, metin üzerinde not alma, grup halinde okuma yapma, yazı boyutunu değiştirme ve metnin altını çizme gibi çeşitli etkinlikler yapmalarını sağlamaktadır. Buradan hareketle, geleneksel anlamda ders kitaplarındaki basılı metinler dijital ortama aktarılarak bu metinlere dayalı okuma ve yazma çalışmaları tablet ya da bilgisayarlar üzerinden yapılabilir.

- Bookcreator, Doodle buddy ve Mystoryapp gibi uygulamalar öğrencilerin çizim yapma, ses, resim ve video ekleme sayesinde çok biçimli hikâye kitapları oluşturmalarını ve yayınlamalarını sağlamaktadır. Öğrencilerin bu uygulamalar üzerinde dijital kitaplar oluşturmalarına yönelik projeler verilebilir. 


\section{Summary}

Purpose and Significance: The nature of literacy as a socio cultural phenomenon has undergone regular and continuous changes (Leu, Kinzer, Coiro, Castek, \& Henry, 2013; Leu, McVerry, O’Byrne, Kiili, \& Zawilinski, 2011; Leu, Zawilinski, Forzani, \& Timbrell, 2015; Leu, Everett-Cacopardo, Zawilinski, Mcverry, \& O 'byrne, 2011). Growing technologies and social forces are the main factors influencing the nature of literacy (Leu et al., 2013). In addition to these factors, economic changes, social pressures, democratization and cultural changes have a role in transforming literacy (Leu, 2000; Leu, Kinzer, Coiro, \& Cammack, 2004). These transformations have brought about a rapid increase in information and communication technology usage rates. To be literate today requires new skills, strategies, practices, and dispositions as well as reading and writing skills based on traditional printed materials. To be fully literate depends on the individual's ability to communicate with the world in both written and verbal forms using information and communication technologies. Thus, the purpose of the current study is to review the new literacy theoretical framework, give information about recent research trends on new literacy, and make some suggestions to policy-makers, researchers and teachers. In accordance with this purpose, i) the duallevel new literacy theory is examined, ii) online reading and writing research in recent years is looked at, iii) information about technology integration in literacy training is given, iv) the concept of the digital divide is discussed and finally v) various research and practice recommendations are introduced.

Dual-level Theory of New Literacy: It is difficult to define a concept that is constantly changing. Today, efforts to define literacy have been made according to different theories and perspectives such as literacy as discourse (Gee \& Handford, 2013), multimodality (Kress, 2003), multiliteracy (New London Group, 1996), information and communication technologies literacy (International ICT Literacy Panel, 2002), and digital literacy (Martin, 2006). Researchers have attempted to sum up these theories and views under a single umbrella, with the dual-level theory of New Literacies (Leu et al., 2015; Leu et al., 2015). The dual-level theory of new literacy frames literacy on the levels: lowercase (new literacies) and uppercase (New Literacies). Uppercase New Literacies are broader and permanent. They consist of many nested viewpoints. Lowercase new literacies chane-more rapidly and consist of more specific tools and areas (Leu et al., 2011; Forzani \& Maykel, 2013).

Integrating Technology into Literacy Education: “To become fully literate in today's world, students must become proficient in the new literacies of 21st-century technologies. As a result, literacy educators have a responsibility to effectively integrate these new technologies into the curriculum, preparing students for the literacy future they deserve" (International Reading Association, 2009). However, schools are continuing to use traditional texts, beliefs and genres in literacy education (Lapp et al., 2012). In recent years, many tools and applications such as digital book creating, digital reading and writing, multimodal composition, cooperative writing and the graphics 
organizer have emerged to allow teachers to integrate them into reading and writing education.

Research on Online Reading in Digital Enviroments: The internet is a reading and literacy issue, not a technology issue (Leu, 2006, p.6). The Reading concept in digital environments adds a new meaning to reading action and has brougt about new proposals (Hutchison \& Colwell, 2015). Different skills, dispositions and strategies are needed to read digital texts (Lankshear \& Knobel, 2011). For this reason, researchers call reading in digital environments "online research and comprehension". Online research and comprehension is one of the key research areas that the lowercase new literacies theory examines. This perspective consider online reading as a process of problem-based inquiry (Leu et al., 2013; Leu et al., 2015). "Online research and comprehension is a self-directed process of constructing texts and knowledge while engaged in several online reading practices: identifying important problems, locating information, critically evaluating information, synthesizing information, and communicating information" (Leu et al., 2013, p.1163-1164).

Research on Online Writing in Digital Enviroments: When examining the writing literature, traditional writing research and teaching focus on spelling, handwriting, constructing a sentence and paragraph, the teaching of writing strategies and processbased writing. These studies and practices are based on cognitive, motivational and socio-cultural theories and models. In recent years, concepts and applications such as hypertext, online reading and writing, word processing, internet and multimodal text, the meaning of being a writer and the nature of writing instruction have brought about changes. For this reason, traditional pen-paper based writing and sharing in the classroom environment no longer fit into today's world.

It is very difficult to address the issue of technology integration in writing instruction from a single point of view or theoretical approach. Looking at the research that integrates technology into the teaching of writing, it appears that many theoretical perspectives, research methodologies and social practices are utilized. Some of the theoretical frameworks that focus on technology and writing are as follows: the simple writing model (Berninger et al., 2002), lowercase new literacies theory (Leu et al., 2016), multimodality in writing (Kress, 2003; Walsh, 2010), sociocultural theory (Vygotsky, 1978) and activity theory (Engstrom, 1999).

Digital Divide and New Literacy: The concept of the digital divide is used to express the gap between individuals at upper and lower socio-economic levels in terms of their having Access to information and communication technologies (Organisation for Economic Co-operation and Development [OECD], 2014; Van Dijk, 2006). It is emphasized in various studies that there is a reading gap between students coming from different socio-economic levels in terms of traditional literacy skills. Various studies show that students from different socio-economic levels differ in their use of computers, internet and technology in home and school environments (Leu, Forzani, Rhoads, Maykel, Kennedy \& Timbrell, 2014; Li \& Ranieri, 2013). Some studies have 
demonstrated that students' online research and comprehension scores differ according to their socio-economic level (Henry, 2007; Leu et al., 2014).

Conclusion and Recommendations: To conclude, literacy is a constantly changing phenomenon as a result of technological, social and cultural transformations. Skills that were sufficient to succeed in the world of 20-30 years ago are not enough nowadays. To be literate today requires new skills, strategies, practices, and dispositons because traditional printed material-based reading and paper pen-based writing are not isomorphic with online reading and writing. Teachers have a great responsibility in this regard. They need to integrate various information and communication technologies into their literacy education. Thus, students will be able to identify important questions, access information, evaluate information, synthesize information from various sources, and create online meaning and content. 


\section{Kaynakça}

Afflerbach, P., \& Cho, B.Y. (2009). Identifying and describing constructively responsive comprehension strategies in new and traditional forms of reading. In S. E. Israel \& G. G. Duffy (Eds.), Handbook of research on reading comprehension (pp.69-90). New York, NY: Routledge.

Afflerbach, P., \& Cho, B. Y. (2010). Determining and describing reading strategies: Internet and traditional forms of reading. In H. S. Waters \& W. Schneider (Eds.), Metacognition, strategy use, and instruction (pp. 201-225). New York, NY: Guilford.

Anwaruddin, S. M. (2015). ICTs in language and literacy education in Bangladesh: A critical review. Current Issues in Education, 18(1), 1-13.

Baker, E. A., Pearson, P. D., \& Rozendal, M. S. (2010). Theoretical perspectives and literacy studies an exploration of roles and insights. In E. A. Baker (Eds.), New literacies: Multiple perspectives on research and practice (pp. 1-22). New York: Guilford.

Beach, R. (2012). Use of digital tools and literacies in the English Language Arts classroom. Research in the Schools, 19(1), 45-59.

Berninger, V. W., Vaughan, K., Abbott, R. D., Begay, K., Coleman, K. B., Curtin, G., ... \& Graham, S. (2002). Teaching spelling and composition alone and together: Implications for the simple view of writing. Journal of Educational Psychology, 94(2), 291-304.

Berninger, V. W., Abbott, R. D., Augsburger, A., \& Garcia, N. (2009). Comparison of pen and keyboard transcription modes in children with and without learning disabilities. Learning Disability Quarterly, 32(3), 123-141.

Bogard, J. M., \& McMackin, M. C. (2012). Combining traditional and new literacies in a 21 st-century writing workshop. The Reading Teacher, 65(5), 313-323.

Castek, J. , Zawilinski , L. , McVerry , G. , O ’ Byrne , I. , \& Leu , D.J. ( 2011 ). The new literacies of online reading comprehension: New opportunities and challenges for students with learning difficulties. In C. Wyatt-Smith, J. Elkins , \& S. Gunn (Eds.), Multiple perspectives on difficulties in learning literacy and numeracy (pp.91-110). New York, NY : Springer.

Castek, J. M. (2008). How do 4 and 5 grade students acquire the new literacies of online reading comprehension? Exploring the contexts that facilitate learning (Unpublished doctoral dissertation). University of Connecticut, Storrs.

Chen, C. M., \& Chen, F. Y. (2014). Enhancing digital reading performance with a collaborative reading annotation system. Computers and Education, 77, 67-81. https://doi.org/10.1016/j.compedu.2014.04.010

Coiro, J., Sekeres, D. C., Castek, J., \& Guzniczak, L. (2014). Comparing the quality of third, fourth, and fifth graders' social interactions and cognitive strategy use during structured online inquiry. Journal of Education, 194(2), 1-15.

Coiro, J. (2011). Predicting reading comprehension on the internet: contributions of offline reading skills, online reading skills, and prior knowledge. Journal of Literacy Research: A Publication of the Literacy Research Association, 43(4), 352392. https://doi.org/10.1177/1086296X11421979 
Coiro, J., \& Dobler, E. (2007). Exploring the online reading comprehension strategies used by sixth-grade skilled readers to search for and locate information on the Internet. Reading Research Quarterly, 42(2), 214-257. https://doi.org/10.1598/RRQ.42.2.2

Connelly, V., Gee, D., \& Walsh, E. (2007). A comparison of keyboarded and handwritten compositions and the relationship with transcription speed. British Journal of Educational Psychology, 77(2), 479-492.

Cordero, K., Nussbaum, M., Ibaseta, V., Otaíza, M. J., Gleisner, S., González, S., ... \& Chiuminatto, P. (2015). Read Create Share (RCS): A new digital tool for interactive reading and writing. Computers \& Education, 82, 486-496.

Crook, C., \& Bennett, L. (2007). Does using a computer disturb the organization of children's writing?. British Journal of Developmental Psychology, 25(2), 313-321.

Esmer, B., \& Ulusoy, M. (2015). Sınıf öğretmen adaylarının elektronik ortamlarda okuma becerilerinin değerlendirilmesi. Uluslararası Sosyal Araştırmalar Dergisi, 8(37), 734-746.

Engstrom, Y. (1999). Activity theory and individual and social transformation. In Y. Engstrom, R. Miettinen, \& R. Punamaki (Eds.), Perspectives on activity theory (pp. 19-38). Cambridge, UK: Cambridge University.

Forzani, E., \& Maykel, C. (2013). Evaluating a representative state sample of connecticut seventh-grade students' ability to critically evaluate online information (ORCA Report 6) Retrived from

http://www.orca.uconn.edu/orca/assets/File/Research\%20Reports/PROJECT\%20R EPORT\%20\%236\%20Forzani\%26Maykel.pdf

Gee, J. \& Handford, M. (2013). The routledge handbook of discourse analysis. Abingdon: Taylor \& Francis.

Handsfield, L. J., Dean, T. R., \& Cielocha, K. M. (2009). Becoming critical consumers and producers of text: Teaching literacy with Web 1.0 and Web 2.0. The Reading Teacher, 63(1), 40-50.

Henry, L. A., Castek, J., O’Byrne, W. I., \& Zawilinski, L. (2012). Using peer collaboration to support online reading, writing, and communication: An empowerment model for struggling readers. Reading and Writing Quarterly, 28(3), 279-306. https://doi.org/10.1080/10573569.2012.676431

Henry, L. A.(2007). Exploring new literacies pedagogy and online reading comprehension among middle school students and teachers: Issues of social equity or social exclusion? (Unpublished doctoral dissertation). University of Connecticut, Storrs.

Howell, E. (2017). Pokémon GO: Implications for literacy in the classroom. The Reading Teacher, 70(6), 729-732.

Hutchison, A. (2012). Literacy teachers' perceptions of professional development that increases integration of technology into literacy instruction. Technology, Pedagogy and Education, 21(1), 37-56. https://doi.org/10.1080/1475939X.2012.659894

Hutchison, A., Beschorner, B., \& Schmidt-Crawford, D. (2012). Exploring the use of the iPAD for literacy learning. Reading Teacher, 66(1), 15-23. https://doi.org/10.1002/TRTR.01090 
Hutchison, A., \& Colwell, J. (2015). Bridging technology and literacy: Developing digital reading and writing practices in grades $K-6$. Lanham, MD: Rowman \& Littlefield.

Hutchison, A., \& Reinking, D. (2011). Teachers' perceptions of integrating information and communication technologies into literacy instruction: A national survey in the United States. Reading Research Quarterly, 46(4), 312-333. https://doi.org/10.1002/RRQ.002

Hutchison, A., \& Woodward, L. (2014). A planning cycle for integrating digital technology into literacy instruction. Reading Teacher, 67(6), 455-464. https://doi.org/10.1002/trtr.1225

ICT Literacy Panel. (2002). Digital transformation: A framework for ICT literacy. Princeton, NJ: Educational Testing Service. Retrieved from http://www.ets.org/Media/Tests/Information_and_Communication_Technology_Lit eracy/ictreport.pdf

International Reading Association. (2009). New literacies and 21st-century technologies. Newark, DE: International Reading Association.

Jones, J.S. \& Rice, M.L. (2017). Exploring classroom microblogs to improve writing of middle school students, Journal of Interactive Online Learning, 15(1), 26-41.

Kiili, C., Laurinen, L., Marttunen, M., \& Leu, D. J. (2012). Working on understanding during collaborative online reading. Journal of Literacy Research, 44(4), 448-483. https://doi.org/10.1177/1086296X12457166

Kress, G. (2003). Literacy in the new media age. London: Routledge.

Lankshear, C., \& Knobel, M. (2011). New literacies: Everyday practices and social learning. Berkshire, England: Open University Press.

Larson, L.C. (2010). Digital readers: The next chapter in e-Book reading and response. Reading Teacher, 64(1), 15-22.

Lapp, D., Moss, B., \& Rowsell, J. (2012). Envisioning new literacies through a lens of teaching and learning. Reading Teacher, 65(6), 367-377. https://doi.org/10.1002/TRTR.01055

Leu, D.J., Jr. (2000). Literacy and technology: Deictic consequences for literacy education in an information age. In M.L. Kamil, P.B. Mosenthal, P.D. Pearson, \& R. Barr (Eds.), Handbook of reading research (Vol. 3, pp.743-770). Mahwah, NJ: Erlbaum.

Leu, DJ Jr, Kinzer C.K., Coiro J, \& Cammack, D. (2004). Toward a theory of new literacies emerging from the Internet and other information and communication technologies. In R.B. Ruddell \& N.J. Unrau (eds) Theoretical models and processes of reading (5th ed., pp. 1570-1613). Newark, DE: International Reading Association.

Leu, D. J. (2006). New literacies, reading research, and the challenges of change: A deictic perspective. (NRC Presidential Address). In J. Hoffman, D. Schallert, C. M. Fairbanks, J. Worthy, \& B. Maloch (Eds.) The 55th Yearbook of the National Reading Conference (1-20). Milwaukee, WI: National Reading Conference.

Leu, D.J., Everett-Cacopardo, H., Zawilinski, L., McVerry, J.G., O’Byrne, W. I. (2012). The new literacies of online reading comprehension. In C.A. Chapelle, (Ed.) The 
Encyclopedia of Applied Linguistics. (pp. 4239-4247). Oxford, UK: WileyBlackwell.

Leu , D.J. , Kulikowich , J. , Sedransk , N. , \& Coiro , J . ( 2009-2014 ). Assessing online reading comprehension: The ORCA Project. [Research grant funded by the U.S. Department of Education, Institute of Education Sciences]. Retrieved from www.orca.uconn.edu/orca-project/project-overview

Leu, D. J., Kinzer, C. K., Coiro, J., Castek, J., \& Henry, L. A. (2013). New literacies: A Dual-level theory of the changing nature of literacy, instruction, and assessment. In D. E. Alvermann, N. J. Unrau, \& R. B. Ruddell (Eds.), Theoretical models and processes of reading (Sixth Edit., pp. 1150-1181). Newark, DE: International Reading Association.

Leu , D.J. , Forzani , E. , Rhoads , C. , Maykel ,C. , Kennedy , C. , \& Timbrell , N . (2014). The new literacies of online research and comprehension: Rethinking the reading achievement gap. Reading Research Quarterly, 50(1), 37-59.

Leu, D. J., Slomp, D., Zawilinski, L. \& Corrigan, J. (2016). Writing research from a new literacies lens. In C. A. MacArthur, S. Graham, \& J. Fitzgerald (Eds.) Handbook of writing research (2nd ed.). New York, NY: Guilford Press.

Leu, D. J., \& Maykel, C. (2016). Thinking in new ways and in new times about reading. Literacy Research and Instruction, 55(2), 122-127. https://doi.org/10.1080/19388071.2016.1135388

Leu, D. J., McVerry, O’Byrne, Kiili, C., \& Zawilinski, L. (2011). The new literacies of online reading comprehension: Expanding the literacy and learning curriculum Donald. Journal of Adolescent \& Adult Literacy, 55(1), 5-14. https://doi.org/10.1598/JA

Leu, D. J., Zawilinski, L., Forzani, E., \& Timbrell, N. (2015). Best practices in teaching the new literacies of online research and comprehension. In L.B. Gambrell \& L.M. Morrow (Ed.), Best practices in literacy instruction (5th ed., pp. 343-364). New York: Guilford.

Li, Y., \& Ranieri, M. (2013). Educational and social correlates of the digital divide for rural and urban children: A study on primary school students in a provincial city of China. Computers \& Education, 60(1), 197-209.

Liu, C. C., Liu, K. P., Chen, W. H., Lin, C. P., \& Chen, G. D. (2011). Collaborative storytelling experiences in social media: Influence of peer-assistance mechanisms. Computers \& Education, 57(2), 1544-1556.

Martin, A. (2006). Literacies for the digital age. In A. Martin \& D. Madigan (Eds.), Digital literacies for learning (pp. 3-25). London, UK: Facet.

McDermott, P., \& Gormley, K. a. (2016). Teachers' use of technology in elementary reading lessons. Reading Psychology, 37(1), 121-146. https://doi.org/10.1080/02702711.2015.1009592

McGrail, E., \& Davis, A. (2011). The influence of classroom blogging on elementary student writing. Journal of Research in Childhood Education, 25(4), 415-437.

Milli Eğitim Bakanlığı. (2017). Türkçe dersi ögretim programı (İlkokul ve Ortaokul 1, 2, 3, 4, 5, 6, 7 ve 8. Sinıflar). Ankara: Milli Eğitim Basımevi. http://mufredat.meb.gov.tr/ProgramDetay.aspx?PID=222 sayfasından erişilmiştir. 
Merchant, G. (2009). Literacy in virtual worlds. Journal of research in reading, 32(1), 38-56.

New London Group (1996). A pedagogy of multiliteracies: Designing social futures. Harvard Educational Review, 66, 60-92.

OECD. (2001). Understanding the digital divide. Paris: OECD. Retreived from https://www.oecd.org/sti/1888451.pdf

O’Neal, L. J., Gibson, P., \& Cotten, S. R. (2017). Elementary school teachers' beliefs about the role of technology in 21st-century teaching and learning. Interdisciplinary Journal of Practice, Theory, and Applied Research, 34(3), 1-15. https://doi.org/http://dx.doi.org/10.1080/07380569.2017.1347443

Pang, S., Reinking, D., Hutchison, A., \& Ramey, D. (2015). South Korean teachers ' perceptions of integrating information and communication technologies into literacy instruction. Education Research International, 2015, 1-13.

Passig, D., \& Maidel-Kravetsky, J. (2016). The impact of collaborative online reading on summarizing skills. Education and Information Technologies, 21(3), 531-543. https://doi.org/10.1007/s10639-014-9337-5

Pifarré, M., Li, L. (2012). Teaching how to learn with a wiki in primary education: What classroom interaction can tell us. Learning, Culture and Social Interaction, 1(2), 102-113.

Pruden, M., Kerkhoff, S. N., Spires, H. A., \& Lester, J. (2017). Enhancing writing achievement through a digital learning environment: Case studies of three struggling adolescent male writers. Reading \& Writing Quarterly, 33(1), 1-19.

Reardon, S. F., \& Galindo, C. (2009). The Hispanic-White achievement gap in math and reading in the elementary grades. American Educational Research Journal, 46(3), 853-891.

Reardon, S. F. (2011). The widening academic achievement gap between the rich and the poor: New evidence and possible explanations. In G. J. Duncan \& R. J. Murnane (Eds.), Whither opportunity? Rising inequality and the uncertain life chances of low-income children (pp. 91-116). New York: Russell Sage Foundation. https://doi.org/10.3102/00028312042002305

Rideout, V. J., Foehr, U. G., \& Roberts, D. F. (2010). Generation M2: Media in the lives of 8- to 18-year-olds. Menlo Park, CA: Henry J. Kaiser Family Foundation.

Sessions, L., Kang, M. O., \& Womack, S. (2016). The neglected "R": Improving writing instruction through iPad apps. TechTrends, 60(3), 218-225.

Schmar-Dobler, E. (2003). Reading on the Internet: The link between literacy and technology. Journal of adolescent \& adult literacy, 47(1), 80-85.

Sormunen, E., González-Ibáñez, R., Kiili, C., Leppänen, P. T., Mikkilä-Erdmann, M., Erdmann, N., \& Escobar-Macaya, M. (2018). A performance-based test for assessing students' online inquiry competences in schools. In S. Kurbanoğlu, et al. (Ed.), Proceedings of the European Conference on Information Literacy (ECIL). Communications in Computer and Information Science, vol 810 (pp. 673-682). Cham: Springer.

Sylvester, R., \& Greenidge, W. L. (2009). Digital storytelling: Extending the potential for struggling writers. The Reading Teacher, 63(4), 284-295. 
Taboada, A., \& Guthrie, J. (2006). Contributions of student questioning and prior knowledge to construction of knowledge from reading information text. Journal of Literacy Research, 38(1), 1-35. https://doi.org/10.1207/s15548430jlr3801_1

Türkiye İstatistik Kurumu (2016). Hanehalkı bilişim teknolojileri kullanım araştırması. http://www.tuik.gov.tr/PreHaberBultenleri.do?id=21779 sayfasından erişilmiştir.

Türkiye İstatistik Kurumu (2013). 06-15 yaş grubu çocuklarda bilişim teknolojileri kullanımı ve medya. http://www.tuik.gov.tr/ PreHaberBultenleri.do?id=15866 sayfasından erişilmiştir.

Yamaç, A., \& Ulusoy, M. (2016). The effect of digital storytelling in improving the third graders' writing skills. International Electronic Journal of Elementary Education, 9(1), 59-86.

Vasudevan, L., Schultz, K., \& Bateman, J. (2010). Rethinking composing in a digital age: Authoring literate identities through multimodal storytelling. Written Communication, 27(4), 442-468.

Van Dijk, J. A. (2006). Digital divide research, achievements and shortcomings. Poetics, 34(4), 221-235.

Vygotsky, L. S. (1978). Mind in society: The development of higher psychological processes. Cambridge, MA: Harvard University.

Walsh, M. (2010). Multimodal literacy: What does it mean for classroom practice?. Australian Journal of Language and Literacy, 33(3), 211-239.

Wollscheid, S., Sjaastad, J., Tømte, C., \& Løver, N. (2016). The effect of pen and paper or tablet computer on early writing-a pilot study. Computers \& Education, 98, 7080.

Wollscheid, S., Sjaastad, J., \& Tømte, C. (2016). The impact of digital devices vs. Pen (cil) and paper on primary school students' writing skills-A research review. Computers \& Education, 95, 19-35.

Zawilinski, L. (2012). An exploration of a collaborative blogging approach to literacy and learning: A mixed method study (Unpublished doctoral dissertation). University of Connecticut, Storrs.

This is an Open Access article distributed under the terms of the Creative CommonsAttributionNonCommercial-ShareAlike 4.0 International (CC BY-NC-SA 4.0). For further information, you can refer to https://creativecommons.org/licenses/by-nc-sa/4.0/ 